Marquette University Law School

Marquette Law Scholarly Commons

Faculty Publications

Faculty Scholarship

2017

\title{
Why and How the Supreme Court Should Have Decided O’Bannon v NCAA
}

Matthew J. Mitten

Marquette University Law School, matt.mitten@marquette.edu

Follow this and additional works at: http://scholarship.law.marquette.edu/facpub

Part of the Law Commons

Publication Information

Matthew J. Mitten, Why and How the Supreme Court Should Have Decided O’Bannon v. NCAA, 62

Antitrust Bull. 62 (2017)

\section{Repository Citation}

Mitten, Matthew J., "Why and How the Supreme Court Should Have Decided O’Bannon v NCAA" (2017). Faculty Publications. 683.

http://scholarship.law.marquette.edu/facpub/683

This Article is brought to you for free and open access by the Faculty Scholarship at Marquette Law Scholarly Commons. It has been accepted for inclusion in Faculty Publications by an authorized administrator of Marquette Law Scholarly Commons. For more information, please contact 


\title{
Why and How the Supreme Court Should Have Decided O'Bannon v NCAA
}

\author{
Matthew J. Mitten*
}

Abstract

Despite requests by both parties, the United States Supreme Court refused to grant a writ of certiorari in O'Bannon $v$. NCAA, the first federal appellate court decision holding that an NCAA student-athlete eligibility rule violates section 1 of the Sherman Act. The Ninth Circuit ruled that NCAA rules prohibiting intercollegiate athletes from receiving any revenue from videogames and telecasts incorporating their names, images, or likenesses unreasonably restrain economic competition among its member universities in the college education market in which these athletes purchase higher education services and sell their athletic services, which violates federal antitrust law. Circuit court rulings conflict regarding whether student-athlete eligibility rules are commercial restraints subject to the Sherman Act, and lower courts have inconsistently interpreted and applied NCAA v Board of Regents of University of Oklahoma, the Supreme Court's only intercollegiate athletics antitrust law precedent. The Supreme Court's refusal to resolve this conflict continues the significant judicial confusion regarding how antitrust law constrains the NCAA's governance of intercollegiate athletics, which has evolved into a multibillion dollar part of the entertainment industry with millions of fans and more than 450,000 student-athletes. Its decision not to do also creates uncertainty regarding how lower courts will resolve pending antitrust challenges to other NCAA amateurism rules and input market restraints such as limits on the duration and maximum number of athletic scholarships per sport as well as transfer rules. This article makes some recommendations for applying section 1 to NCAA student-athlete eligibility rules and input market restraints, which will better promote consumer welfare, protect student-athletes' economic rights, and permit the NCAA to promote the unique features of intercollegiate sports without unwarranted judicial micromanagement.

Key words: O'Bannon v NCAA; amateurism rules; input market restraint; rule of reason; less restrictive alternative.

\section{Introduction}

O'Bannon $v N C A A^{l}$ is the first federal appellate court decision holding that a National Collegiate Athletic Association (NCAA) student-athlete eligibility rule unreasonably restrains trade in violation of section 1 of the Sherman Act. More specifically, the Ninth Circuit ruled that NCAA amateurism rules prohibiting student-athletes from receiving any revenue from

\footnotetext{
* Professor of Law and Executive Director, National Sports Law Institute and LL.M. in Sports Law Program for Foreign Lawyers, Marquette University Law School; President, Sports Lawyers Association. The views expressed herein are solely my own and are not those of any of these organizations. The author expresses his gratitude to Jessica Goldstein for her excellent research and editorial assistance.

${ }^{1} 802$ F.3d 1049 (9th Cir. 2015), cert. denied, 137 S. Ct. 277 (2016).
}

As published: Matthew J. Mitten, Why and How the Supreme Court Should Have Decided O'Bannon $v$. NCAA, Antitrust Bulletin, Vol. 62, Issue No. 1, pp.62-90, Copyright (C) 2017, Reprinted by permission of SAGE Publications. https://doi.org/10.1177/0003603X17691383. 
videogames and telecasts incorporating their names, images, or likenesses unreasonably restrain economic competition among its member universities in the college education market in which student-athletes purchase higher education services and sell their athletic services. Both sides petitioned for a writ of certiorari to review O'Bannon, but the Supreme Court denied both petitions despite: 1) conflicting rulings among circuit courts regarding whether student-athlete eligibility rules are commercial restraints subject to the Sherman Act; 2) lower courts' inconsistent interpretation and application of NCAA $v$ Board of Regents of University of Oklahoma (Board of Regents), ${ }^{2}$ its only intercollegiate athletics antitrust law precedent; and 3) pending section 1 litigation challenging other NCAA student-athlete eligibility rules and input market restraints, which would benefit significantly from its guidance.

In particular, there is sharp disagreement among federal appellate courts regarding whether student-athlete eligibility rules and their enforcement are valid as a matter of law, or whether they should be subject to rule of reason scrutiny. There also are differing judicial views concerning whether maintenance of NCAA-defined "amateurism" is appropriately characterized as a procompetitive justification. In addition, there is no principled and uniform jurisprudence applying section 1 to NCAA input market restraints that is consistent with generally accepted and sports industry-specific antitrust law principles.

In prior scholarship, I advocated that NCAA amateurism eligibility rules prohibiting price competition for student-athletes' playing services constitute commercial restraints subject to section 1 rule of reason analysis rather than being judicially presumed to be valid. ${ }^{3}$ However, I recognize that the principled application of section 1 to input market restraints such as NCAA student-athlete eligibility rules is a very complex, expensive, and time consuming endeavor and that using antitrust law to create free market economic competition for intercollegiate athletes' services may conflict with the achievement of legitimate social welfare objectives in higher education. Thus, in subsequent scholarship, my co-authors and I argued in favor of alternative intercollegiate athletics regulatory systems along with Congressional antitrust immunity if certain conditions to achieve these objectives are satisfied, which continues to be my preferred approach. ${ }^{4}$ Given the uncertainty of future Congressional adoption of either proposal, this article asserts that the Supreme Court should have granted certiorari in O'Bannon and suggests how it

${ }^{2} 468$ U.S. 85 (1984).

${ }^{3}$ Matthew J. Mitten, Applying Antitrust Law to NCAA Regulation of "Big Time" College Athletics: The Need to Shift From Nostalgic 19th and 20th Century Ideals of Amateurism to the Economic Realities of the 21 st Century, 11 MARQ. SPORTS L. REV. 1 (2000); Matthew J. Mitten, University Price Competition for Elite Students and Athletes: Illusions and Realities, 36 So. TEX. L. REV. 59 (1995) [hereinafter Mitten, University Price Competition].

${ }^{4}$ Matthew J. Mitten \& Stephen F. Ross, A Regulatory Solution to Better Promote the Educational Values and Economic Sustainability of Intercollegiate Athletics, 92 ORE. L. REV. 837 (2014); Matthew J. Mitten, James L. Musselman \& Bruce W. Burton, Targeted Reform of Commercialized Intercollegiate Athletics, 47 SAN DIEGO L. REV. 779 (2010). 
should have decided this case, thereby clarifying the appropriate application of section 1 to intercollegiate athletics input market restraints as well as providing guidance regarding its application to professional sports and potentially other joint ventures.

This article begins by briefly comparing the key characteristics of NCAA intercollegiate athletics (particularly Division I FBS football and men's basketball) to major league professional team sports. It then summarizes judicial application of section 1 to professional sports league labor market restraints, which is followed by a corresponding discussion of its application by courts to NCAA input market restraints, primarily those affecting student-athletes, including the NCAA amateurism rule at issue in O'Bannon. Next, it summarizes the parties' respective petitions for a writ of certiorari and supporting amicus briefs, which identify several important antitrust issues requiring Supreme Court resolution. It concludes by making some recommendations for judicial application of section 1 to NCAA student-athlete eligibility rules and other input market restraints, which is consistent with Board of Regents as well as Supreme Court and lower court precedent applying antitrust law to professional sports leagues. Judicial adoption of these recommendations would promote consumer welfare by maintaining the unique features of college sports that distinguish them from professional sports, while also prohibiting predominantly anticompetitive NCAA student-athlete eligibility rules and other input market restraints without inappropriate judicial micromanagement of intercollegiate athletics.

\section{Similarities and Differences between NCAA Sports and Professional Team Sports}

NCAA intercollegiate athletics and North American major league professional team sports both are entertainment products consisting of athletic competitions with uncertain outcomes - requiring some degree of competitive balance among teams playing the game - that have substantial commercial value because of their consumer popularity. The NCAA and North American major league professional leagues produce many of the same sports (e.g., baseball, basketball, football, hockey, soccer), which are played pursuant to essentially the same on-field rules. Like the NFL and NBA, ${ }^{5}$ Division I FBS football and men's basketball annually generate multi-billion dollar revenues from live fan attendance, the sale of broadcasting rights, sponsors, and other sources. ${ }^{6}$

${ }^{5}$ For the 2014-2015 season, Forbes estimated that the NBA earned $\$ 5.2$ billion in revenue. Forbes Releases 18th Annual NBA Team Valuations, FORBES (Jan. 20, 2016), http://www.forbes.com/sites/forbespr/2016/01/20/forbes-releases-18th-annual-nba-teamvaluations/\#529f71e76e3e. Forbes also estimated that the NFL earned over $\$ 13.3$ billion in revenue for the 2015-2016 season,. Jason Belzer, Thanks to Roger Goodell, NFL Revenues Projected to Surpass $\$ 13$ Billion in 2016, ForBES (Feb. 29, 2016), http://www.forbes.com/sites/jasonbelzer/2016/02/29/thanks-to-roger-goodell-nfl-revenuesprojected-to-surpass-13-billion-in-2016/\#12e2f44f3278.

${ }^{6}$ In 2014, which was the first year of the College Football Playoff, bowl game revenues generated by Division I FBS conferences and schools exceeded $\$ 500$ million. In 2016, the NCAA extended its television contract, with both CBS and Turner Sports, through 2032 for its 
Professional sports leagues generally are comprised of privately owned, for-profit member clubs that have the right to operate a team in a particular geographical location. Professional team sport athletes are employees of their respective clubs, andthey have the right to unionize under federal labor law. ${ }^{7}$ Major league professional players generally have done so, and their respective labor unions (e.g., NFL Players Association, NBA Players Association) collectively bargain the "wages, hours, and other working conditions" for all league players in accordance with the National Labor Relations Act (NLRA). ${ }^{8}$

By comparison, the highest level of intercollegiate athletics are produced by nonprofit institutions of higher education and regulated by the NCAA, ${ }^{9}$ an association of more than 1,100

Division I men's basketball tournament, and will receive more than \$1 billion annually beginning in 2024. The Big Ten's new media rights deals with Fox and ESPN will generate $\$ 2.64$ billion over the next six years; and Michigan, Ohio State, and UCLA signed apparel contracts collectively worth more than $\$ 700$ million. Glenn Wong, Accelerating the Pace of Change for Division I Athletic Directors, SpORTs Bus. J., Nov. 28-Dec. 4, 2016, at 30. According to the Knight Commission on Intercollegiate Athletics, annual intercollegiate sports revenue generated by the Division I Power Five Conferences, which consists of the 65 member universities of the Atlantic Coast Conference, Big Ten Conference, Big Twelve Conference, Pac Twelve Conference, and Southeastern Conference, will be $\$ 2.8$ billion by 2020. Jake New, College Sports' Slow Pace of Change, InSIDE HiGHER ED (Dec. 7, 2016), https://www.insidehighered.com/news/2016/12/07/over-three-decades-pushing-sports-reformknight-commission-touts-smallsignificant?utm_source=Inside+Higher+Ed\&utm_campaign=101f9b37a9DNU20161207\&utm_medium=email\&utm_term=0_1fcbc04421-101f9b37a9197510237\&mc_cid=101f9b37a9\&mc_eid=bb78605517. Total fan attendance has slowing become the area of college sports that draws the least amount of revenue. For example, in 2013, the NCAA earned a total of $\$ 797$ million in revenue, with $\$ 702$ million coming from TV contracts, $\$ 71.71$ million coming from ticket sales to the Division I men's basketball tournament, and the rest presumably coming from attendance at the Division I women's basketball tournament and e at other, men's and women's NCAA championship competitions. College Sports (NCAA)—Statistics \& Facts, STATISTA, https://www.statista.com/topics/1436/collegesports-ncaa/ (last visited Dec. 16, 2016).

${ }^{7}$ Am. League of Prof'1 Baseball Clubs \& Ass'n of Nat'1 Baseball League Umpires, 180 N.L.R.B. 190 (1969) (National Labor Relations Board recognition that employees of professional sports leagues (and by implication their member clubs) have right to unionize under federal labor law).

829 U.S.C. $\$ \$ 151$ et seq.

${ }^{9}$ The NCAA, originally named the Intercollegiate Athletic Association, was founded in 1905 to change college football rules to make the sport safer in response to President Theodore Roosevelt's threat to ban it after several college players died while playing football. Rodney K. 
member colleges and universities organized into three divisions. The NCAA also organizes and sponsors annual championships for all its recognized sports except Division I FBS

football—which selects its national champion pursuant to the College Football Playoff system, an agreement among its ten member conferences and independent individual universities.

Although very few athletic departments annually generate revenues exceeding their costs, ${ }^{10}$ "in an extremely competitive higher education market, academic leaders use intercollegiate athletics as a catalyst and means" to achieve broader university objectives, which include attracting well qualified students who are fans of or participants in the university's athletic teams; recruiting and retaining high quality faculty members; increasing fund raising; and enhancing support for the institution from a variety of constituencies. ${ }^{11}$

The NCAA's objective is "to maintain intercollegiate athletics as an integral part of the educational program and the athlete as an integral part of the student body and, by so doing, retain a clear line of demarcation between intercollegiate athletics and professional sports." 12 According to the NCAA, "[s]tudent-athletes shall be amateurs in an intercollegiate sport, and their participation should be motivated primarily by education and by the physical, mental and social benefits to be derived. Student participation in intercollegiate athletics is an avocation, and student-athletes should be protected from exploitation by professional and commercial enterprises." 13 In other words, the NCAA seeks to preserve the amateur nature of college sports as a component of higher education and to ensure competitive balance on the playing field. ${ }^{14}$

This idealized NCAA philosophy has been characterized as the "amateur/education model" of intercollegiate athletics. ${ }^{15}$ Although college sports have been commercialized since their inception in the $1850 \mathrm{~s},{ }^{16}$ it aptly describes Division III intercollegiate

Smith, A Brief History of the National Collegiate Athletic Association's Role in Regulating Intercollegiate Athletics, 11 MARQ. SPORTS L. REV. 9, 10-13 (2000).

${ }^{10}$ The most recent report published by the NCAA indicates that only 24 Division I university athletic departments generated positive net revenues in 2014. 2004-14 NCAA REVENUES \& EXPENSES DIVISION I REPORT 28 (2015).

${ }^{11}$ Mitten, Musselman \& Burton, supra note 4, at 792.

12 2016-17 NCAA DiviSION I MANUAL art. 1.3.1 (2016) [hereinafter NCAA MANUAL].

${ }^{13}$ Id. art. 2.9.

${ }^{14}$ It also establishes requirements and guidelines to protect participating student-athletes' health and safety. See, e.g., 2014-15 NCAA SporTs Medicine HANDBooK (2015), http://www.ncaapublications.com/productdownloads/MD15.pdf.

15 Timothy Davis, Intercollegiate Athletics: Competing Models and Conflicting Realities, 25 RUTGERS L.J. 269, 270 (1994). 
athletics — participating college athletes are not permitted to receive athletic scholarships—as well as Division I and II women's and men's sports that do not generate net revenues.

There is a contractual relationship between intercollegiate athletes and their respective universities ${ }^{17}$ into which NCAA academic, amateurism, and other eligibility rules are incorporated. All athletes must be full-time students who meet minimum initial academic eligibility and progress towards degree requirements; they also have a maximum duration of intercollegiate athletics eligibility (generally 4-5 years). ${ }^{18}$ Division I and II intercollegiate athletes are permitted to receive full or partial athletic scholarships, but NCAA "amateurism rules" cap the scholarship's value and restrict the economic benefits the athletes may receive from their respective universities, or third parties, for their playing services. ${ }^{19}$ The rules also prohibit athletes from receiving any payments for college athletics accomplishments or fame. ${ }^{20}$

Because these sports generate multi-billion dollars revenues, Division I FBS football and men's basketball are based on a "commercial/education model" 21 of intercollegiate sports. However, commercialized college sports are "not subject to the same economic forces as purely commercial enterprises like professional sports" for the following reasons:

.... [A]thletic directors seek to maximize the commercial return on big-time sports, [but] nonprofit universities do not distribute the profits generated by commercially successful football and men's basketball programs to shareholders. Indeed, athletic directors are typically motivated to spend surplus revenues from football and men's basketball programs on socially worthy causes, which often include a broad range of intercollegiate sports for elite athletes that do not generate sufficient revenues to pay for their costs, and occasionally subsidies for university academic and educational programs. ${ }^{22}$

${ }^{16}$ Mitten \& Ross, supra note 4, at 840 (observing that " $[\mathrm{t}]$ he first intercollegiate athletic competition, a rowing competition between Harvard and Yale in 1852, was sponsored by a railroad seeking to attract passengers via its new route to the lake on which this event took place.").

${ }^{17}$ See, e.g., Taylor v. Wake Forest Univ., 191 S.E.2d 379 (N.C. App. 1972).

18 See generally MATtheW J. MitTen, ET AL., SPORTS LAW AND REgulation: CASES, MAterials, AND PROBlems 123-27 (3d ed. 2013).

${ }^{19}$ NCAA MANUAL, supra note 12, art. 16.11.2

${ }^{20} I d$. art. 12.1.2.1.5.

${ }^{21}$ Davis, supra note 15 , at 279.

${ }^{22}$ Mitten \& Ross, supra note 4 , at 841-42. 
Similar to NFL and NBA coaches ${ }^{23}$ several Division I FBS football and men's basketball head coaches for these college sports earn multi-million dollar annual salaries ${ }^{24}$ Twelve Division I FBS assistant football coaches make at least $\$ 1$ million. ${ }^{25}$ Although 2013-14 average annual NFL and NBA player salaries were \$2 million and \$4.9 million, ${ }^{26}$ respectively, reflecting their substantial economic value to their teams, the NCAA's amateurism rules prohibit all intercollegiate athletes, including Division I FBS football and men's basketball players, who also have substantial economic value to their universities, ${ }^{27}$ from being paid any cash compensation for their playing services. The only (and maximum) direct economic benefit they are permitted to

${ }^{23}$ During the 2015-16 NBA season, Gregg Popovich, head coach of the San Antonio Spurs, earned \$11 million, making him the highest paid NBA coach. Top 10 Highest Paid NBA Coaches in 2015-16, SPORTIGE (Jan. 14, 2016), http://sportige.com/top-10-highest-paid-nbacoaches-90570/. For the 2016 season, Sean Payton, head coach of the New Orleans Saints, will earn $\$ 8$ million, making him the highest paid NFL coach. Nat Berman, Top 10 NFL Coaching Salaries for the 2016 Season, MoNEY INC (Aug. 9, 2016), http://moneyinc.com/nfl-coachingsalaries-for-the-2016-season/.

${ }^{24}$ In 2016, the top 25 highest-paid men's college basketball coaches all made more than $\$ 2.2$ million, with the top three earning \$6.4 million (John Calipari, Kentucky), \$6.03 million (Mike Krzyzewski, Duke), and \$6 million (Rick Pitino, Louisville) million. Top 25 Highest-Paid College Basketball Coaches, SPORTING News (Apr. 6, 2016), http://www.sportingnews.com/ncaa-basketball/photos/highest-paid-richest-college-basketballhoops-coaches-calipari-coach-k/2oij4dpoac5y1a82xm2pk2mb6/slide/429806. The top 10 highest-paid football coaches made more than $\$ 4.4$ million each, with the top three earning \$7.09 million (Nick Saban, Alabama), \$7.004 million (Jim Harbaugh, Michigan), and \$5.86 million (Urban Meyer, Ohio State). The Highest-Paid College Football Coaches in 2016, AOL (Aug. 25, 2016), http://www.aol.com/article/2016/08/25/who-are-the-highest-paid-collegefootball-coaches-in-2016/21458856/\#slide=4027352\#fullscreen.

${ }^{25}$ Steve Berkowitz \& Christopher Schnaars, \$1M Club Grows in College Football, USA TODAY, Dec. 8, 2016, at $1 \mathrm{~A}$.

${ }^{26}$ Kurt Badenhausen, Average MLB Player Salary Nearly Doubles NFL's, but Still Trails NBA's, FORBES (Jan. 23, 2015), http://www.forbes.com/sites/kurtbadenhausen/2015/01/23/average-mlbsalary-nearly-double-nfls-but-trails-nba-players/\#3f1f1ac0269e.

${ }^{27}$ It is estimated that the average Division I FBS football is worth $\$ 163,869$ per year. Cork Gaines, The Average University of Texas Football Player is Now Worth More Than \$670,000 Per Year, Bus. INSIDER (Oct. 19, 2016), http://www.businessinsider.com/college-football-playervalue-2016-10. 
receive is the value of a full cost-of-attendance athletic scholarship at their respective universities. $^{28}$

Although a full cost of attendance athletics scholarship has a substantial economic value ${ }^{29}$ and is at least arguably "pay" in the form of in kind higher educational benefits for college sports playing services, courts have refused to characterize student-athletes as "employees" for purposes of state worker's compensation laws. ${ }^{30}$ In Rensing v. Indiana State Univ. Bd. of Trustees, the Indiana Supreme Court observed that "scholarship recipients are considered to be students seeking advanced educational opportunities and are not considered to be professional athletes." 31 Courts also have ruled that student-athletes are not employees under the federal Fair Labor Standards Act because "the long tradition of amateurism in college sports, by definition, shows that student athletes - like all other amateur athletes_participate in their sports for reasons wholly unrelated to immediate compensation ... and have done so for over 100 years under the NCAA — without any real expectation of earning an income."32

In Northwestern University and College Athletes Players Association, the National Labor Relations Board (NLRB) determined that, even if Northwestern University scholarship football

${ }^{28}$ At the 2015 NCAA Annual Convention, the Power Five Conferences exercised their autonomy authority by voting to permit their members to offer full athletic scholarships equal in value to the full cost-of-attendance at their respective universities. Michelle Brutlag Hosick, Autonomy Schools Adopt Cost of Attendance Scholarships, NCAA.ORG (Jan. 18, 2015), http://www.ncaa.org/about/resources/media-center/autonomy-schools-adopt-cost-attendancescholarships. Beginning with the 2015-2016 academic year, this legislation enables universities to provide athletic scholarships that include "[s]tipends, determined by institutions under federally created guidelines.” Mitch Sherman, Full Cost of Attendance Passes 79-1, ESPN (Jan. 18, 2015), http://espn.go.com/college-sports/story/_id/12185230/power-5-conferences-passcost-attendance-measure-ncaa-autonomy-begins.

${ }^{29}$ For example, its estimated annual value is $\$ 68,095$ for student-athletes at Northwestern University, and \$34,752 for an in-state student-athlete at the University of California, Los Angeles, a public university. Christopher Smith, Full Cost of Attendance: What Will it Mean for Power Five Players?, SATURDAY Down S. (Apr. 10, 2015), http://www.saturdaydownsouth.com/sec-football/full-cost-of-attendance-explained/.

${ }^{30}$ See, e.g., Rensing v. Ind. State Univ. Bd. of Trs., 444 N.E.2d 1170 (Ind. 1983); Waldrep v. Tex. Emp'rs Ins. Ass'n, 21 S.W.3d 692 (Tex. Ct. App. 2000); Coleman v. W. Mich. Univ., 336 N.W.2d 224 (Mich. Ct. App. 1983).

${ }^{31}$ Rensing, 444 N.E.2d at 1174.

${ }^{32}$ Berger v NCAA, 2016 WL 7051905, at*5 (7th Cir. 2016). 
players are employees under the NLRA, "it would not effectuate the policies of the Act to assert jurisdiction." 33 The Board stated:

[o]ur decision is primarily premised on a finding that, because of the nature of sports leagues (namely the control exercised by the leagues over the individual teams) and the composition and structure of [Division I] FBS football (in which the overwhelming majority of competitors are public colleges and universities over which the Board cannot assert jurisdiction), it would not promote stability in labor relations to assert jurisdiction in this case. ${ }^{34}$

Observing that "this case involves novel and unique circumstances," 35 the NLRB explained:

[S]cholarship players are unlike athletes in undisputedly professional leagues, given that [they] are required, inter alia, to be enrolled full time as students and meet various academic requirements, and they are prohibited by NCAA regulations from engaging in many of the types of activities that professional athletes are free to engage in, such as profiting from the use of their names or likenesses. . . . [E]ven if scholarship players were regarded as analogous to players for professional sports teams who are considered employees for purposes of collective bargaining, such bargaining has never involved a bargaining unit consisting of a single team's players, where the players for competing teams were unrepresented or entirely outside the Board's jurisdiction.

... As in professional sports . . . uniform rules of competition and compliance with them ensure the uniformity and integrity of individual games, and thus league competition as a whole. There is thus a symbiotic relationship among the various teams, the conferences, and the NCAA. As a result, labor issues directly involving only an individual team and its players would also affect the NCAA, the Big Ten, and the other member institutions. Many terms applied to one team therefore would likely have ramifications for other teams. . . . [S] uch an arrangement is seemingly unprecedented; all previous Board cases concerning professional sports involve leaguewide bargaining units. ${ }^{36}$

${ }^{33}$ N. Univ. \& Coll. Athletes Players Ass'n, 362 N.L.R.B. No. 167, 2015 WL 4882656, at *1 (Aug. 17, 2015).

${ }^{34}$ Id. at $* 3$.

${ }^{35} I d$. at $* 4$.

${ }^{36} I d$. at $* 4-5$. 
Some states have laws that effectively prohibit intercollegiate athletes at public universities from unionizing under state labor laws applicable to public employees. ${ }^{37}$ As a result of Northwestern University and these state laws, intercollegiate athletes currently do not have the legal right to unionize and collectively bargain any of the terms of their contracts with NCAA universities, which effectively would immunize any agreed terms from antitrust challenge pursuant to the nonstatutory labor exemption.

\section{Judicial Application of Section 1 to Professional Sports League Labor Market Restraints}

Professional sports league clubs' collectively imposed labor market restraints on players, such as fixing their compensation, rules determining their eligibility to play in the league, or preventing their ability to choose their teams, are input market restraints that are subject to and may violate section 1 under well-established precedent. In Mandeville Island Farms v. American Crystal Sugar Co., ${ }^{38}$ the Supreme Court held that an agreement among California sugar refiners who sell sugar in interstate commerce to pay a uniform price for sugar beets grown in California states a claim under section 1. "It is clear that the agreement is the sort of combination condemned by the Act, even though the price-fixing was by purchasers, and the persons specially injured under the treble damage claim are sellers, not customers or consumers." 39 It reasoned that the Sherman Act "is comprehensive in its terms and coverage, protecting all who are made victims of the forbidden practices by whomever they may be perpetrated" of the Act is competition," which "cannot be flouted" 41 by concerted price fixing by group of buyers.

Although Mandeville Island Farms held that fixing the price of inputs necessary to produce a product is per se illegal, courts generally analyze the legality of restraints that fixed the price of professional athletes' wages under the rule of reason. In Brown v. Pro Football, Inc., ${ }^{42}$ a Washington, D.C. federal district court rejected plaintiffs' claim that an agreement among NFL clubs "to pay all Developmental Squad players a flat sum of $\$ 1,000$ per week, regardless of any individual player's background, skill, or potential, is a per se violation of the

${ }^{37}$ See, e.g., OHIO REV. CODE ANN. $\$ 3345.56$ (West 2016) ("Notwithstanding any provision of the Revised Code to the contrary, a student attending a state university as defined in section 3345.011 of the Revised Code is not an employee of the state university based upon the student's participation in an athletic program offered by the state university."). See also MICH. COMP. LAWS § 423.201(1)(e)(iii) (2016).

38334 U.S. 219 (1948).

${ }^{39} I d$. at 235 .

${ }^{40} I d$. at 236.

${ }^{41}$ Id. at 243.

421992 WL 88039 (D.D.C. 1992), rev'd on other grounds, 50 F.3d 1041(D.C. Cir. 1995), aff'd, 518 U.S. 231 (1996). 
Sherman Act." ${ }^{, 43}$ The court analyzed it under the rule of reason because the clubs are engaged in a joint venture to produce an entertainment product (i.e., on-field competition among professional football teams), which cannot be produced by a single club and necessarily requires their cooperation, and they offered legitimate procompetitive justifications for this restraint. Applying the rule of reason, the court initially determined that this restraint has the significant anticompetitive effect of precluding all Developmental Squad players from negotiating their salary with any NFL clubs. It explained that if the restraint "has legitimate business purposes which would promote competition, the court must then balance [its] 'anticompetitive evils' ... against its "procompetitive virtues." "44 It found that the clubs did not prove this salary restraint "enhances competition in the labor market for professional football players" 45 or promotes onfield competitive balance among them. Because the clubs failed to establish it is necessary to achieve either procompetitive objective, the court held that its significant anticompetitive effects rendered it unlawful under the rule of reason. It granted plaintiffs' motion for summary judgment because the undisputed facts established that the salary restraint has clear net anticompetitive effects, thereby obviating the need for any fact finding and balancing by a jury or the court.

Courts generally have held that unilaterally determined league rules — which are the product of an agreement among its clubs that are competitors for players' services ${ }^{46}$ - establishing player eligibility requirements, ${ }^{47}$ a draft for entry level players, ${ }^{48}$ and restrictions on the ability of veteran players to choose a new team after their current contracts expire $^{49}$ also violate the rule of reason. ${ }^{50}$ For example, in Smith v. Pro Football (which Brown relied on), the District of Columbia Circuit explained:

${ }^{43}$ Id. at $* 6$.

${ }^{44} I d$. at $* 9$.

${ }^{45}$ Id. at $* 9$.

${ }^{46}$ See, e.g., McNeil v. NFL, 790 F. Supp. 871 (D. Minn. 1992).

${ }^{47}$ Clarett v. NFL, 306 F. Supp. 2d 379 (S.D.N.Y.), rev'd on other grounds, 369 F.3d 124 (2d Cir. 2004). Some early cases such as Denver Rockets v. All-Pro Management, Inc., 325 F. Supp. 1049 (C.D. Cal. 1971), held that such restraints are per se illegal, but these cases subsequently have been effectively overruled by American Needle and Board of Regents, which require application of the rule of reason to most sports industry restraints. See infra notes 55-56, 67 and accompanying text.

${ }^{48}$ Smith v. Pro Football, Inc., 593 F.2d 1173, 1178 (D.C. Cir. 1978).

${ }^{49}$ Mackey v. NFL, 543 F.2d 606 (8th Cir. 1976); McNeil v NFL, 1992 WL 315292 (D. Minn. 1992).

${ }^{50}$ Fraser v. Major League Soccer LLC, 284 F.3d 47 (1st Cir.), cert. denied, 537 U.S. 885 (2002), is one of the few cases in which a major professional sports league labor market restraint was 
a player draft can survive scrutiny under the rule of reason only if it is demonstrated to have positive, economically procompetitive benefits that offset its anticompetitive effects, or, at the least, if it is demonstrated to accomplish legitimate business purposes and to have a net anticompetitive effect that is insubstantial. $^{51}$

It upheld the district court's bench trial verdict that the then-existing 16-round NFL player draft is an unreasonable restraint of trade:

The draft is anticompetitive in its effect on the market for players' services, because it virtually eliminates economic competition among buyers for the services of sellers. The draft is allegedly "procompetitive" in its effect on the playing field; but the NFL teams are not economic competitors on the playing field, and the draft, while it may heighten athletic competition and thus improve the entertainment product offered to the public, does not increase competition in the economic sense of encouraging others to enter the market and to offer the product at lower cost. Because the draft's "anticompetitive" and "procompetitive" effects are not comparable, it is impossible to "net them out" in the usual rule-ofreason balancing. The draft's "anticompetitive evils," in other words, cannot be balanced against its "procompetitive virtues," and the draft be upheld if the latter outweigh the former. In strict economic terms, the draft's demonstrated procompetitive effects are nil. ${ }^{52}$

Smith also held that an anticompetitive labor market restraint will be invalidated if "significantly less anticompetitive alternatives" exist to achieve the league's procompetitive objective of achieving competitive balance among its clubs. ${ }^{53}$ For example, permitting multiple clubs to draft a player, a draft with fewer rounds "applying only to the most talented players and enabling their 'average' brethren to negotiate in a 'free market," or to replace the draft with

found not to violate antitrust law. Plaintiffs, a group of professional soccer players, failed to prove that the challenged restraints imposed by Major League Soccer, a U.S. league, have significant anticompetitive effects because there is an international market for the services of professional soccer players "to which players can turn, as a practical matter, for alternate opportunities for employment." Id. at 63.

${ }^{51}$ Smith, 593 F.2d at 1188.

${ }^{52}$ Id. at 1186. See Clarett v. NFL, 306 F. Supp. 2d 379, 409 (S.D.N.Y.), rev'd on other grounds, 369 F.3d 124 (2d Cir. 2004) (holding that the NFL cannot justify rule that "limits competition in the player personnel market but enhances competition in the market for sports entertainment" because the later is "a different market").

${ }^{53}$ Smith, 593 F.2d at 1187. See Clarett, 306 F. Supp. 2d at 410 ("The antitrust laws do not tolerate a policy that restrains trade - even if there is some procompetitive benefit — when a policy that results in less prejudice to competition would be equally effective."). 
"revenue-sharing to equalize the teams' financial resources [as] a method of preserving "competitive balance.",54

Smith's holding that the anticompetitive effects of a labor market restraint cannot be justified by procompetitive effects that enhance a sports league's ability to compete in the entertainment market, an output market different from the restrained input market, has been effectively overruled. In American Needle, Inc. v. NFL, ${ }^{55}$ the Supreme Court subsequently recognized that a professional sports league's interest in maintaining competitive balance among its member clubs is "legitimate and important," which is "unquestionably an interest that may well justify a variety of collective decisions made by the teams" under the rule of reason. American Needle strongly suggests that a sports league can justify a labor market restraint reasonably necessary to promote competitive balance among its member clubs. ${ }^{56}$

Because North American major professional league players have chosen to unionize and courts have construed the scope of the nonstatutory labor exemption very broadly, there have been very few antitrust suits challenging professional sports labor market restraints for the past 25 years. This exemption precludes the parties (i.e. league, clubs, union, and players) from challenging the terms of a collective bargaining agreement ("CBA") on antitrust grounds, which furthers the strong federal labor policy permitting employees, including professional athletes, to unionize and collectively bargain their wages and working conditions. ${ }^{57}$ In a series of cases from 1976-1987, federal appellate courts held that CBA terms are not subject to antitrust challenge, thereby permitting league clubs and the players union to agree to contract terms that otherwise may violate antitrust law. ${ }^{58}$

In Woodv. NBA, the Second Circuit explained:

${ }^{54}$ Smith, 593 F.2d at 1188.

55560 U.S. 183, 204 (2010).

${ }^{56}$ See generally id. This view is consistent with Supreme Court antitrust precedent not involving the sports industry recognizing that a reduction in intrabrand economic competition among sellers of the same branded product may have the procompetitive effect of preserving or enhancing interbrand economic competition among sellers of competing products. See Cont'l T.V., Inc. v GTE Sylvania, Inc., 433 U.S. 36 (1977). See also Sullivan v. NFL, 34 F.3d 1091, 1111-113 (1st Cir. 1994) (procompetitive effects in a closely related market (i.e., those that enhance a professional sports league's ability to more effectively compete with other forms of entertainment) should be balanced against a restraint's anticompetitive effects).

${ }^{57}$ Connell Constr. Co. v. Plumbers, Local 100, 421 U.S. 616, 622 (1975).

58 See, e.g., Wood v. NBA, 809 F.2d 954 (2d Cir. 1987); McCourt v. Cal. Sports, Inc., 600 F.2d 1193 (6th Cir. 1979); Reynolds v. NFL, 584 F.2d 280 (8th Cir. 1978). 
Freedom of contract is an important cornerstone of national labor policy .... Courts cannot hope to fashion contract terms more efficient than those arrived at by the parties who are to be governed by them. . .

[It] is particularly important in the context of collective bargaining between professional athletes and their leagues. Such bargaining relationships raise numerous problems with little or no precedent in standard industrial relations. As a result, leagues and player unions may reach seemingly unfamiliar or strange agreements. If courts were to intrude and to outlaw such solutions, leagues and their player unions would have to arrange their affairs in a less efficient way. ${ }^{59}$

In Brown v. Pro Football, Inc., ${ }^{60}$ the Supreme Court held that the nonstatutory labor exemption immunizes all restraints on the labor market for players' services (e.g., player drafts, team or individual player salary caps, and player free agency restrictions) from antitrust challenge - as long as there is an ongoing collective bargaining process between the league and the players union. If there is, federal labor law exclusively governs labor relations between the parties.

\section{Judicial Application of Section 1 to NCAA Input Market Restraints Affecting College Athletes}

Prior to NCAA v. Board of Regents, ${ }^{61}$ the Supreme Court's 1984 landmark decision regarding the application of antitrust law to NCAA governance of intercollegiate athletics, lower courts consistently rejected antitrust challenges to NCAA rules creating input market restrictions affecting coaches and student-athletes. In Hennessey v. NCAA, ${ }^{62}$ the Fifth Circuit ruled that, although the NCAA has no blanket antitrust immunity merely because it is a nonprofit joint venture of institutions of higher education, limiting the number of coaches for particular intercollegiate sports is not an unreasonable restraint of trade. Some courts held that NCAA student-athlete eligibility rules to promote amateurism in college sports and/or to protect its members' academic standards are noncommercial restraints that "[d]o not come within the purview of the Sherman Act."63 Others concluded, without any supporting evidence, that such rules and their enforcement are a reasonable means of achieving these objectives and promoting fair competition in intercollegiate athletics. ${ }^{64}$

\footnotetext{
${ }^{59}$ Wood, 809 F.2d at 961.

${ }^{60} 518$ U.S. 231 (1996).

61468 U.S. 85 (1984).

${ }^{62}$ Hennessey v. NCAA, 564 F.2d 1136 (5th Cir. 1977).

${ }^{63}$ Coll. Athletic Placement Serv., Inc. v. NCAA, No. 74-1144, 1974 WL 998, at *4 (D.N.J.), aff'd, 506 F.2d 1050 (3d Cir. 1974). See Jones v. NCAA, 392 F. Supp. 295 (D. Mass. 1975).

${ }^{64}$ See, e.g., Justice v. NCAA, 577 F. Supp. 356 (D. Ariz.1983).
} 
In Board of Regents, the Court confirmed that the NCAA is subject to antitrust law because its regulatory activities affect interstate commerce. It noted that the "NCAA is an association of schools which compete against each other to attract television revenues, not to mention fans and athletes;" ${ }^{65}$ thereby recognizing that its rules and decisions are the product of an agreement among its members that satisfies section 1's concerted action requirement. Although it affirmed the Tenth Circuit's holding that the NCAA's exclusive sale of college football television broadcasting rights violates section 1 , it reversed its determination that it is per se illegal horizontal price fixing and output limitation. Because intercollegiate athletics is "an industry in which horizontal restraints on competition are essential if the product[-athletic competition among NCAA universities- ] is to be available at all, ${ }^{, 66}$ the Court held that the rule of reason applies in analyzing this restraint's "impact on competitive conditions."

Because it limits the total number of televised college football games below the output in a free market (and fixes the price of broadcast rights), the NCAA's television plan has clear anticompetitive effects and harms consumer welfare. Thus, the NCAA has "a heavy burden of establishing an affirmative defense which competitively justifies this apparent deviation from the operations of a free market. ${ }^{\prime 68}$ The Court recognized maintenance of brand differentiation and competitive balance as two procompetitive justifications for NCAA restraints with anticompetitive effects. It stated: "the NCAA seeks to market a particular brand of footballcollege football" and "[t]he identification of this 'product' with an academic tradition differentiates [it] from . . . professional sports to which it might otherwise be comparable." ${ }^{.69}$ It explained that "the preservation of the student-athlete in higher education adds richness and diversity to intercollegiate athletics and is entirely consistent with the goals of the Sherman Act. ${ }^{, 70}$ Because the NCAA football television plan was not necessary to further either of these procompetitive objectives, the Court held that it violated the rule of reason.

In dicta, the Court stated: "[i]n order to preserve the character and quality of the 'product' [college sports], athletes must not be paid, must be required to attend class, and the like. ${ }^{, 71}$ It observed: "The NCAA plays a critical role in the maintenance of a revered tradition of amateurism in college sports. There can be no question but that it needs ample latitude to play

${ }^{65}$ Bd. of Regents, 468 U.S. at 99.

${ }^{66} I d$. at 101.

${ }^{67} I d$. at 103.

${ }^{68} I d$. at 113.

${ }^{69} I d$. at 101.

${ }^{70} I d$. at 120.

${ }^{71} I d$. at 101. 
that role.",72 It also agreed with the NCAA's contention that "maintaining competitive balance among amateur athletic teams is legitimate and important.,"73

Although it was not necessary to consider any less restrictive alternatives to support its conclusion that the NCAA football television plan was an unreasonable restraint because it was "not even arguably tailored to serve" competitive balance among NCAA schools, the Court noted several other NCAA restrictions "better tailored" and "clearly sufficient" to achieve this objective. $^{74}$

After Board of Regents, federal appellate courts generally continued to rule that NCAA student-athlete eligibility rules and their enforcement by disciplinary sanctions are valid as a matter of law because they are 1) noncommercial restraints not subject to antitrust scrutiny; or 2) commercial restraints that are a presumptively reasonable means of promoting brand differentiation, competitive balance, or amateurism in intercollegiate athletics.

In Banks v. NCAA, ${ }^{75}$ the Seventh Circuit held that the NCAA's "no-draft" and "no agent" rules, which resulted in a Notre Dame student-athlete's loss of eligibility to play college football when he entered the NFL draft and agreed to be represented by an agent in that sport, is not a commercial restraint that causes antitrust injury. It reasoned that "[n]one of the NCAA rules affecting college football eligibility restrain trade in the market for college players because the NCAA does not exist as a minor league training ground for future NFL players but rather to provide an opportunity for competition among amateur students pursuing a collegiate education." "76 Similarly, in Smith v. NCAA, ${ }^{77}$ the Third Circuit dismissed an allegation that the NCAA's postbaccalaureate bylaw, which precluded a graduate student from participating in intercollegiate athletics at a university other than the one at which she earned her undergraduate degree, violates section 1 . The court concluded that "eligibility rules are not related to the NCAA's commercial or business activities;" therefore, "the Sherman Act does not apply."78 Relying on Smith, the Sixth Circuit, in Bassett v. NCAA, ${ }^{79}$ held that the "NCAA's rules on recruiting student athletes, specifically those rules prohibiting improper inducements and

\footnotetext{
${ }^{72} I d$. at 120 .

${ }^{73}$ Id. at 117 .

${ }^{74} I d$. at 119.

75977 F.2d 1081 (7th Cir.), cert. denied, 508 U.S. 908 (1992).

${ }^{76} I d$. at $1089-090$.

77 139 F.3d 180 (3d Cir. 1998).

${ }^{78} I d$. at $185-86$.

79528 F.3d 426 (6th Cir. 2008).
} 
academic fraud, are all explicitly non-commercial." ${ }^{80}$ The court affirmed the dismissal of a section 1 claim by a former college football coach who had been disciplined for violating them.

In $M c$ Cormick v. NCAA, ${ }^{81}$ the Fifth Circuit assumed, without deciding, that NCAA student-athlete amateurism eligibility rules are commercial restraints subject to rule of reason scrutiny. Relying on Board of Regents, it dismissed an allegation that these rules constitute pricefixing in violation of section 1. In upholding their validity as a matter of law, the court explained:

The essential inquiry under the rule-of-reason analysis is whether the challenged restraint enhances competition. Applying this test, we have little difficulty in concluding that the challenged restrictions are reasonable. The Supreme Court indicated strongly in Board of Regents [by stating] ... 'In order to preserve the character and quality of the "product," athletes must not be paid, must be required to attend class, and the like.' . . . The NCAA markets college football as a product distinct from professional football. The eligibility rules create the product and allow its survival in the face of commercializing pressures. The goal of the NCAA is to integrate athletics with academics. Its requirements reasonably further this goal.

... We therefore conclude that the plaintiffs cannot prove any set of facts that would carry their antitrust claim and that the motion to dismiss was properly granted. ${ }^{82}$

In Agnew v. NCAA, ${ }^{83}$ the Seventh Circuit diverged from (or at least clarified) Banks by expressing "the view that the Sherman Act applies to the NCAA bylaws generally" ${ }^{84}$ because despite their nonprofit status, NCAA universities enter into commercial transactions with premier athletes by providing scholarships for their playing services that can generate millions of dollars in revenues. Thus, all NCAA student-athlete eligibility rules and other input market restrictions are commercial restraints. According to the court and consistent with McCormick, "[m]ost — if not all — eligibility rules ... fall comfortably within the presumption of procompetitiveness afforded to certain NCAA regulations" ${ }^{\prime 85}$ despite being commercial restraints.

${ }^{80} I d$. at 433 .

${ }^{81} 845$ F.2d 1338 (5th Cir. 1988).

${ }^{82}$ Id. at 1344-345 (quoting NCAA v. Bd. of Regents, 468 U.S. 85, 102 (1984)). See Smith, 139 F.3d at 187 ("we think that the bylaw so clearly survives a rule of reason analysis that we do not hesitate upholding it by affirming [its dismissal] for failure to state a claim on which relief can be granted").

${ }^{83} 683$ F.3d 328 (7th Cir. 2012).

${ }^{84} \mathrm{Id}$. at 340.

${ }^{85}$ Id. at 343. 
Distinguishing between NCAA student-athlete eligibility rules and other restraints such as a maximum number of allowable scholarships per sport and its then-existent one-year limit on the duration of athletic scholarships, the Seventh Circuit explained the rationale for presuming that eligibility rules are valid for purposes of antitrust law:

The NCAA's limitation on athlete compensation beyond educational expenses... directly advances the goal of maintaining a "clear line of demarcation between intercollegiate athletics and professional sports," and thus is best categorized as an eligibility rule aimed at preserving the existence of amateurism and the student-athlete. The Bylaws at issue in this case, on the other hand, are not directly related to the separation of amateur athletics from pay-forplay athletics, as explained in the preceding paragraphs. Nor do they help preserve the existence of the student-athlete (as a facial matter, anyway), since they actually limit the number of athletes awarded financial aid and the amount of financial aid that an athlete can be awarded. Thus, financial aid rules do not always assist in the preservation of amateurism or the existence of studentathletes, so the regulations at issue cannot be presumptively procompetitive simply because they relate to financial aid. ${ }^{86}$

Two other pre-O'Bannon federal appellate court cases involving input price fixing agreements among universities are relevant regarding the antitrust validity of NCAA input market restraints affecting college athletes. In Law v. NCAA,${ }^{87}$ the Tenth Circuit held that the NCAA's Restricted Earnings Coach (REC) rule limiting the annual compensation of certain Division I entry-level coaches to $\$ 16,000$ violated the "quick look" rule of reason because the NCAA did not prove it furthered a procompetitive justification. Characterizing the REC rule as "a horizontal agreement to fix prices," ${ }^{88}$ the court found it is not "necessary to produce competitive intercollegiate sports." ${ }^{\prime 89}$ It concluded that the NCAA's objectives of retaining entry-level coaching positions and cutting costs are not valid procompetitive justifications.

In United States v. Brown University, ${ }^{90}$ the Antitrust Division alleged that an agreement among the members of the Ivy Overlap Group (the eight Ivy League universities and Massachusetts Institute of Technology) to award financial aid only on the basis of need, to share financial information regarding admitted students, and to jointly develop and apply a uniform need analysis violated section 1 . The Third Circuit held that nonprofit educational institutions' "determination of financial assistance to students is part and parcel of the process of setting

\footnotetext{
${ }^{86} I d$. at 344 .

${ }^{87} 134$ F.3d 1010 (10th Cir. 1998).

${ }^{88} I d$. at 1020.

${ }^{89} I d$. at 1021.

${ }^{90} 5$ F.3d 658 (3d Cir. 1993).
} 
tuition and thus a commercial transaction" to which the Sherman Act applies. ${ }^{91}$ Because this restraint "eliminate[s] price competition for talented students," it is facially anticompetitive and "cannot be justified solely on the basis of social welfare concerns" 92 such as increasing the socioeconomic diversity of their student bodies. The court concluded that the full rule of reason applied in determining its reasonableness because defendant MIT offered procompetitive justifications. Citing Board of Regents, it recognized enhanced "consumer appeal of an Overlap education" and "consumer choice" (i.e., providing "students who otherwise would not have been able to afford an Overlap education the opportunity to have one") as procompetitive justifications. $^{93}$

O'Bannon v. NCAA's determination that agreements among universities to fix input market prices must be justified by a procompetitive objective under the rule of reason is consistent with Law and Brown University, although it diverges from circuit court precedent holding that NCAA student-athlete eligibility rules (including those that effectively fix prices) are valid as a matter of law. In O'Bannon, the Ninth Circuit ruled that NCAA amateurism rules preventing current and former Division I basketball and FBS football players from receiving any compensation for the use of their names, images, and likenesses ("NIL compensation rules") in videogames and televised games is a commercial restraint "within the ambit of the Sherman Act."94 It distinguished Smith because the NCAA's postbaccalaureate bylaw is "a true 'eligibility' rule akin to" its academic eligibility rules and those limiting the number of seasons student-athletes can play intercollegiate sports. ${ }^{95}$ Characterizing Bassett's holding that NCAA amateurism rules are noncommercial as "simply wrong," the Ninth Circuit failed to understand its reasoning that "rules that seek to combat commercialism in college sports by preventing schools from competing to pay student-athletes cannot be considered restraints on "commerce." "96 The court disagreed with the NCAA's assertion that its amateurism rules are valid as a matter of law under Board of Regents and found Agnew "unpersuasive" to the extent it supports this contention. ${ }^{97}$ It held that the "amateurism rules' validity must be proved, not presumed." 98

\footnotetext{
${ }^{91} I d$. at 668 .

${ }^{92}$ Id. at 669.

${ }^{93}$ Id. at $674-75$.

${ }^{94}$ O’Bannon v. NCAA, 802 F.3d 1049, 1066 (9th Cir. 2015).

${ }^{95} I d$.

${ }^{96} I d$.

${ }^{97}$ Id. at 1064.

${ }^{98}$ Id.
} 
To determine if the NCAA's NIL compensation rules constitute an unreasonable restraint of trade, the Ninth Circuit applied the same three-step full rule of reason analysis as did the district court:

[1] The plaintiff bears the initial burden of showing that the restraint produces significant anticompetitive effects within a relevant market. [2] If the plaintiff meets this burden, the defendant must come forward with evidence of the restraint's procompetitive effects. [3] The plaintiff must then show that any legitimate objectives can be achieved in a substantially less restrictive manner. ${ }^{99}$

The Ninth Circuit affirmed the following rulings by the district court: based on Mandeville Island Farms, the restraint fixes the price of one element of competition (i.e., NIL rights) at zero in the college education market in which NCAA universities compete for the services of student-athletes; NIL compensation rules serve "the two procompetitive purposes ... [of] integrating academics with athletics, and 'preserving the popularity of the NCAA's product by promoting its current understanding of amateurism;", "100 these rules "do not promote competitive balance, ... do not increase output in the college education market, and ... play a limited role in integrating student-athletes with their schools' academic communities." 101 Although it recognized that "a restraint that broadens choices can be procompetitive," 102 the court rejected the NCAA's assertion that "denying student-athletes compensation apart from scholarships" 103 does. It reasoned that "loosening or abandoning the compensation rules might be the best way to 'widen' recruits range of choices." 104 For example, "athletes might well be more likely to attend college, and stay there longer, if they knew that they were earning some amount of NIL income while they were in school."105

Regarding the less restrictive alternative prong of rule of reason analysis, the Ninth Circuit stated that "plaintiffs must make a strong evidentiary showing" that its proposed alternative is "viable" and "virtually as effective' in serving the procompetitive purposes of the NCAA's current rules, and without significant costs."106 The court observed it "must generally afford the NCAA 'ample latitude' to superintend college athletics" and " plenty of room . . . to

\footnotetext{
${ }^{99} I d$. at 1070.

${ }^{100} I d$. at 1073.

${ }^{101}$ Id. at 1072.

${ }^{102}$ Id.

${ }^{103}$ Id. at 1073.

${ }^{104} I d$.

${ }^{105}$ Id.

${ }^{106} I d$. at 1074 .
} 
preserve the amateur character of intercollegiate athletics." "107 Applying this standard, the panel ruled that allowing NCAA schools to award full cost of attendance scholarships (which have been permissible since August 2015) is a substantially less restrictive alternative to the NCAA's NIL compensation rules, which would be an effective means of integrating academics with athletics and maintaining amateurism in intercollegiate athletics without significantly increasing their costs. It affirmed the district court's injunction requiring the NCAA to allow its members to provide compensation up to the full cost of attending their respective institutions.

The Ninth Circuit majority held that the district court erred in determining that permitting NCAA schools to provide pro rata cash payments to football and basketball players of no less than $\$ 5,000$ for each year of sports participation after they left college or their eligibility expires is also a substantially less restrictive alternative to the NCAA's current NIL compensation rules. ${ }^{108}$ The district court reasoned that no evidence established that "consumer demand for the NCAA's product would decrease if schools were permitted to provide such stipends" or that doing so "would hinder any school's efforts to educate its student-athletes or integrate them into the academic community." 109 They disagreed that "allowing students to be paid NIL compensation unrelated to their education expenses, is 'virtually as effective' in preserving amateurism as not allowing compensation" because not paying student-athletes is precisely what makes them amateurs. " 110 In reaching this conclusion, they effectively ruled that antitrust law permits the NCAA to prohibit student-athletes from receiving "cash payments untethered to their education expenses."111

Acknowledging that his disagreement with the majority "largely boils down to a difference in opinion as the procompetitive interests at stake," the dissenting judge characterized the key issue as "whether allowing student-athletes to be compensated for their NILs is "virtually as effective' in preserving popular demand for college sports as not allowing compensation."112 He cited expert economist testimony that "consumer demand typically does not decrease when athletes are permitted to receive payment, and that this general principle holds true across a wide variety of sports and competitive formats." 113 In his view, this record evidence was sufficient to

${ }^{107} \mathrm{Id}$.

${ }^{108} I d$. at 1076-079. The district court rejected plaintiffs' third proposed less restrictive alternative of permitting student-athletes to receive endorsement income based on the free market value of their individual NIL rights because it would not enable the NCAA to achieve its procompetitive objectives. O’Bannon v. NCAA, 7 F. Supp. 3d 955, 984 (N.D. Cal. 2014).

${ }^{109}$ Id. at 983.

${ }^{110}$ O'Bannon, 802 F.3d at 1076.

${ }^{111} I d$.

${ }^{112}$ Id. at 1081 (Thomas, C.J., dissenting).

${ }^{113}$ Id. 
affirm the district court's finding that a $\$ 5,000$ per year stipend is a substantially less restrictive alternative to achieve this objective.

\section{Proposed Application of Section 1 to NCAA Input Market Restraints Affecting College Athletes}

O'Bannon generated petitions from both parties for a writ of certiorari expressing a wide variety of views regarding how antitrust law should be judicially applied to NCAA studentathlete eligibility rules and input market restraints as well as its broader implications for the sports industry. The NCAA asserted O'Bannon's unprecedented ruling that its amateurism rules violate section 1 conflicts with Board of Regents" holding that "a defining feature" of intercollegiate sports is that "participants must be amateur student-athletes," 114 which is procompetitive and should be upheld as a matter of law-as Agnew, Smith, and McCormick did. It also claimed that $O$ 'Bannon improperly applied a de facto least restrictive alternative standard that improperly second-guesses business decisions to achieve legitimate objectives "without . . . adding that much to competition." 115 In addition, the NCAA contended that O'Bannon encourages antitrust challenges to its rules, and that it "should not have to undergo a full trial (and years of litigation) or face treble damages whenever a plaintiff or counsel hits on a supposedly better way to administer college athletics."116

Three amicus briefs were filed in support of the NCAA's petition. The Bar Association of the District of Columbia Antitrust Law Section expressed concern that O'Bannon exposes educational institutions to potentially broad antitrust liability for rules prohibiting or limiting student-athlete compensation or athletic scholarships for high school sports and nonrevenue generating intercollegiate sports. It advocated that the Supreme Court adopt the following standard: "If the challenged restraint is reasonably necessary to create a new product, and if [it] is socially beneficial (for example, if [it] increases output or consumer choice), then the restraint likely increases consumer welfare, and is presumptively lawful under antitrust's rule of reason." 117 The National Federation of State High School Associations claimed that O'Bannon's "detailed and costly antitrust inquiry, one directed at the core function of defining 'amateurism' itself, promises to hinder the NCAA's future efforts to halt the encroachment of professionalism, with negative consequences for amateur athletics in colleges, and beyond," including

${ }^{114}$ Petition for Writ of Certiorari at 14, NCAA v. O'Bannon, 137 S. Ct. 277 (2016) (No. 151388), 2016 WL 2866087.

115 Id. at 25.

${ }^{116} I d$. at 26.

${ }^{117}$ Brief of Amicus Curiae Bar Association of the District of Columbia Antitrust Law Section in Support of Petitioner at 1-2, NCAA v. O’Bannon, 137 S. Ct. 277 (2016) (No. 15-1388), 2016 WL 3345342. 
interscholastic athletics. ${ }^{118}$ A group of twelve antitrust scholars agreed that O'Bannon inappropriately applied a least restrictive alternative standard because "[o]nce the court found that restricting payments to students was reasonably necessary to the amateurism/integration justifications, it should not have condemned the restraints solely because it thought a different level of athlete compensation was preferable to the level chosen by the NCAA."119 "While increasing allowable payments to students from full grant-in-aid to cost of attendance may be a fairer policy," they asserted that it "is not a judgment the antitrust laws authorize courts to make." 120

The plaintiff student-athletes claimed that the O'Bannon majority's adoption of amateurism as a valid procompetitive interest in determining a proper remedy for the NCAA's antitrust violation contravenes Board of Regents by "remov[ing] the critical question - the effect on consumers - from the analysis, making 'amateurism'. . . an end in itself." 121 Their petition also asserted that the majority inappropriately used less restrictive alternative analysis to require plaintiffs to prove the district court's remedy permitting them to receive deferred trust fund pro rata compensation of $\$ 5,000$ per year of intercollegiate athletics participation was justified. In other words, this requirement "improperly would limit antitrust relief to injunctions that qualify as 'less restrictive alternatives' under the Rule of Reason.", 122

Federal appellate courts' inconsistent application of section 1 to NCAA student-athlete eligibility rules and the foregoing very different views of the parties and amici regarding the important antitrust issues raised by O'Bannon illustrate the need for a principled framework for determining the legality of NCAA student-athlete eligibility rules and other input market restraints. The following recommendations provide a principled framework for applying section 1 in a manner that promotes consumer welfare by permitting the NCAA to maintain the unique features of college sports distinguishing them from professional sports, while prohibiting predominantly anticompetitive NCAA rules without inappropriate judicial micromanagement of intercollegiate athletics. They are consistent with Board of Regents as well as Supreme Court and lower court precedent applying antitrust law to professional sports leagues. In addition, these recommendations would provide guidance to lower courts in resolving pending antitrust

${ }^{118}$ Brief of Amicus Curiae National Federation of State High School Associations in Support of Petitioner at 13, NCAA v. O'Bannon, 137 S. Ct. 277 (2016) (No. 15-1388), 2016 WL 3401625.

${ }^{119}$ Brief of Amici Curiae Antitrust Scholars in Support of Petitioner at 3, NCAA v. O'Bannon, 137 S. Ct. 277 (2016) (No. 15-1388), 2016 WL 3383877.

${ }^{120}$ Id. at 11 .

${ }^{121}$ Petition for Writ of Certiorari at 10-11, O’Bannon v. NCAA, 137 S. Ct. 277 (2016) (No. 15 1167), 2016 WL 1085599.

${ }^{122}$ Id. at 22. 
litigation challenging the legality of other NCAA amateurism rules ${ }^{123}$ as well as other NCAA input market restraints such as a prohibition on multi-year athletic scholarships and cap on their maximum number ${ }^{124}$ and rules preventing Division I basketball and football players from transferring to other NCAA Division I schools without losing athletic eligibility for a year. ${ }^{125}$

\section{A. NCAA Student-Athlete Eligibility Rules and Input Market Restrictions Generally Are Commercial Restraints}

As Board of Regents recognized, NCAA universities are competitors for student-athletes' enrollment as students and their playing services as intercollegiate athletes. In American Needle, the Supreme Court held that rules and agreements among separate economic entities in a joint venture such as a sports league are not immune from section 1 scrutiny merely because their cooperation is necessary to produce their product of sports competition. O'Bannon and Agnew appropriately characterized an athletic scholarship, which is a contract between a university and its student-athletes, as a commercial transaction because it is the underlying basis of a relationship that has substantial economic value for both parties. This view is consistent with

123 There are a group of cases in which Division I men's and women's basketball and FBS football players seek to recover treble damages for NCAA rules limiting the value of their athletic scholarships to less than the full cost-of-attendance in violation of section 1. See, e.g., Hartman v. NCAA, No. 4:15-cv-00178 (N.D. Cal. filed Jan. 13, 2015); Gregory-McGhee v. NCAA, No. 4:14-cv-01777 (N.D. Cal. filed Apr. 17, 2014); Alston v. NCAA, No. 3:14-cv-01011 (N.D. Cal. filed Mar. 5, 2014). In Jenkins v. NCAA, No. 3:14-cv-01678 (D.N.J. filed Mar. 17 , 2014), a group of current and former Division I basketball and FBS football players allege that the NCAA, Pacific 12 Conference, Big Ten Conference, Big Twelve Conference, Southeastern Conference, and Atlantic Coast Conference "entered into what amounts to cartel agreements with the avowed purpose and effect of placing a ceiling on the compensation that may be paid to these athletes for their services [which] are pernicious, a blatant violation of the antitrust laws, have no legitimate pro-competitive justification, and should now be struck down and enjoined" so that the free market can determine the economic value and components of athletic scholarships for Division I basketball and FBS football players. Jenkins was consolidated with those cases and transferred to the Northern District of California before the O'Bannon district court judge. On August 5, 2016, the court denied the NCAA's motion to dismiss these consolidated cases because the "Ninth Circuit's decision in $O^{\prime}$ Bannon simply forecloses one type of relief Plaintiffs previously sought: cash compensation untethered to educational expenses. While O'Bannon is binding on this Court, it does not provide the basis for judgment on the pleadings." In re National Collegiate Athletic Association Athletic Grant-in-Aid Cap Antitrust Litigation, 2016 WL 4154855 at $* 2$ (N.D. Cal. 2016).

${ }^{124}$ Rock v. NCAA, 2013 WL 4479815 (S.D. Ind. 2013).

${ }^{125}$ Vassar v. NCAA, No. 1:2016cv10590 (N.D. Ill. Filed Nov. 14, 2016); Pugh v. NCAA, 2016 WL 5394408 (S.D. Ind. 2016); Deppe v. NCAA, No. 1:16-cv-00528 (S.D. Ind. Filed Mar. 18, 2016). 
Brown University's determination that a university's award of financial aid to students is a commercial transaction to which the Sherman Act is applicable.

NCAA rules are incorporated into its member universities' athletic scholarships, and student-athlete compliance with these rules is a condition of their eligibility to compete in intercollegiate athletics. NCAA amateurism rules "restrict the compensation or things of value that student-athletes may receive or the ways by which they earn compensation"126 and prohibit any price competition among NCAA schools for student-athletes' playing services. To maintain their eligibility to play intercollegiate athletics, NCAA amateurism rules also prohibit studentathletes from receiving any economic benefits or preferential treatment (e.g., free or reduced price goods or services) based on their athletic achievements or fame from others. ${ }^{127}$ NCAA academic eligibility requirements have commercial effects by eliminating an element of nonprice competition among universities, which prevents athletes who do not satisfy them from receiving the economic benefits of free or reduced price higher education. NCAA transfer rules have similar commercial effects by generally requiring a student-athlete who transfers from any member institution to another one to complete a full year of academic residence before being eligible to participate in intercollegiate athletics, which may preclude the receipt of an athletic scholarship with corresponding adverse economic effects. ${ }^{128}$

${ }^{126}$ Gary R. Roberts, The NCAA, Antitrust, and Consumer Welfare, 70 TUL. L. REV. 2631, 2647 (1996).

127 See NCAA MANUAL, supra note 12, art. 16.02.3 (defining an "extra benefit" as "any special arrangement by an institutional employee or representative of the institution's athletics interests to provide a student-athlete or the student-athlete family member or friend a benefit not expressly authorized by NCAA legislation."). See also id. art. 16.2.2 (outlining procedures that are "nonpermissible" for student-athletes, their families, or third-parties when it comes to tickets provided to student-athletes for athletic events); $i d$. art. 16.11.2 (defining specific "nonpermissible" benefits for student-athletes).

${ }^{128}$ Sarah M. Konsky, An Antitrust Challenge to the NCAA Transfer Rules, 70 U. CHI. L. REV. 1581, 1596 (2003) (suggesting that transfer rules are "sufficiently commercial to warrant antitrust scrutiny " because they "further schools' commercial interests in maintaining highquality athletic programs"). The NCAA manuals at all three divisional levels have transfer rules listed under article 14.5; each manual states: "A student who transfers to a member institution from any collegiate institution is required to complete one full academic year of residence at the certifying institution before being eligible to compete for or to receive travel expenses from the member institution, unless the student satisfies the applicable transfer requirements or qualifies for an exception as set forth in this bylaw.'NCAA MANUAL, supra note 12, art. 14.5.1; 2016-17 NCAA DIVISION II MANUAL art. 14.5.1 (2016); 2016-17 NCAA DIVISION III MANUAL art. 14.5.1 (2016). 
Other NCAA input market restraints, such as prohibiting multi-year athletic scholarships or per sport caps on their number, eliminate economic competition among universities for student-athletes. Applying Agnew, in Rock v. NCAA, a federal district court ruled that NCAA limits on the maximum number of Division I football scholarships its member universities could award (eighty-five for Football Bowl Series (FBS) teams, and sixty-three for Football Championship Series (FCS) teams) and prohibitions against multi-year scholarships constitute commercial activity subject to section $1 .^{129}$

However, it would not be appropriate to characterize all NCAA input market regulation as commercial restraints subject to antitrust scrutiny. In Board of Regents, the Supreme Court recognized that the production of intercollegiate sports requires agreement among NCAA members regarding "[a] myriad of rules affecting such matters as the size of the field, the number of players on a team, and extent to which physical violence is to be encouraged or proscribed."130 Although "all restrain the manner in which [NCAA] institutions compete," it would not make sense to classify the rules of the game as commercial restraints. ${ }^{131}$ Based on Board of Regents and because of their de minis anticompetitive effects, NCAA rules and regulation to protect student-athlete health and safety (e.g., pre-participation or return to play medical clearance requirements; drug testing program and sanctions) also are not commercial restraints subject to section 1 . $^{132}$

\section{B. All NCAA Student-Athlete Eligibility Rules Are Subject to Rule of Reason Analysis Except Academic Eligibility Requirements, Which Should Be Valid As a Matter of Law}

For the same reasons that NCAA student-athlete eligibility rules-except player safety regulations - are commercial restraints, it is inappropriate to interpret Board of Regents as creating a presumption that all student-athlete eligibility rules, particularly amateurism rules that fix student-athletes' compensation, are valid as a matter of law. Board of Regents involved a section 1 challenge to an NCAA output market restraint, its exclusive college football television plan that eliminated competition among its member schools regarding the sale of rights to their football games. It did not consider the antitrust validity of any NCAA student-athlete eligibility rules, much less hold that any of them are per se legal. Rather, it held that a price fixing

${ }^{129}$ Rock, 2013 WL 4479815 at *8.

${ }^{130}$ NCAA v. Bd. of Regents, 468 U.S. 85, 101 (1984).

${ }^{131}$ Roberts, supra note 126, at 2633 ("It is unlikely that anyone would seriously allege that 'agreements' by members of an athletic organization defining the shape and size of playing venues, the required equipment, or the rules for the conduct of the game itself would pose antitrust questions.").

132 Neeld v. Nat'l Hockey League, 594 F.2d 1297, 1300 (holding that a NHL bylaw excluding a one-eyed hockey player from the league does not violate section 1 as a matter of law because it "is not motivated by anticompetitiveness . . . any anticompetitive effect is at most de minimis [and it is] incidental to the primary purpose of promoting safety"). 
agreement among NCAA member schools imposes "a heavy burden of establishing an affirmative defense which competitively justifies this apparent deviation from the operations of a free market." ${ }^{\prime 13}$ Consistent with American Needle and Law, O'Bannon held that a price fixing agreement among sports league or organization members is subject to rule of reason scrutiny. It properly rejected contrary holdings by Bassett and McCormack as well as Agnew's broad view that "[m]ost—if not all—eligibility rules" are presumptively procompetitive.

In contrast to the NCAA's rules fixing student-athletes' compensation from its member schools and prohibiting their receipt of economic benefits from other sources, its academic eligibility requirements (e.g., initial eligibility and progress towards degree rules) define the core or essential characteristics of its unique brand of athletic competition among intercollegiate student-athletes. In Board of Regents, the Supreme Court observed that "the NCAA seeks to market a particular brand of football — college football" and "the identification of this 'product' with an academic tradition differentiates [it]" from professional sports. ${ }^{134}$ It concluded that "the preservation of the student-athlete in higher education adds richness and diversity to intercollegiate athletics and is entirely consistent with the goals of the Sherman Act."135 In O'Bannon, although the challenged restraint was not an NCAA academic eligibility rule, both the Ninth Circuit and district court determined that "integrating academics and athletics" is a procompetitive justification. ${ }^{136}$ Accordingly, it is appropriate that NCAA academic eligibility requirements, although properly characterized as commercial restraints, be presumed to be procompetitive and valid as a matter of law without rule of reason analysis. ${ }^{137}$

\section{Judicial Application of the Rule of Reason Should Be Consistent With Antitrust Law Objectives}

A renowned antitrust law scholar describes the prevailing application of the rule of reason as follows:

Today, the courts pursue rule of reason analysis through a verbal sequence something like this: first, the plaintiff has the burden to show a prima facie anticompetitive restraint, which requires proof of power and a threat of anticompetitive effects. The burden then shifts to the defendant to show some

${ }^{133}$ Bd. of Regents, 468 U.S. at 113.

${ }^{134}$ Id. at $101-02$.

${ }^{135}$ Id. at 120 .

${ }^{136}$ O’Bannon v. NCAA, 802 F.3d 1049, 1073 (9th Cir. 2015), 7 F. Supp. 3d 955, 1005 (N.D. Cal. 2014).

${ }^{137}$ Smith v. NCAA, 139 F.3d 180, 187 (3d Cir.1998) (upholding dismissal of antitrust challenge to NCAA postbaccalaureate bylaw because it "clearly survives a rule of reason analysis"); Bowers v. NCAA, 9 F. Supp. 2d 460, 497-98 (D.N.J. 1998) (dismissing claim that NCAA academic eligibility rules violate section 1) 
justification for the restraint. If the defendant succeeds, the burden shifts back to the plaintiff, who can then show that the proffered justification was either a pretense or else that a substantially equivalent benefit could be achieved by a less restrictive alternative. If a less restrictive alternative is available, the court condemns the restraint because the same effects could have been achieved in a less anticompetitive manner. If no such alternative is offered or available, the court must balance the anticompetitive effects of the restraint against the nonpretextual defense. ${ }^{138}$

Although NCAA input market restraints with clear anticompetitive effects and no procompetitive justifications (e.g., REC rule) can be invalidated under a "quick look" or truncated rule of reason, as occurred in Law, Board of Regents generally requires use of the full rule of reason in analyzing NCAA student-athlete eligibility rules or other input market restraints adversely affecting their economic interests. In analyzing the NIL compensation rules, O'Bannon applied a three-step full rule of reason process, which considers a restraint's anticompetitive effects, procompetitive effects, and less restrictive alternatives without any balancing to determine its net competitive effects. ${ }^{139}$

By contrast, Law's full rule of reason analysis consists of four-steps, with the last one requiring such balancing if the parties satisfy their respective burdens under the first three steps:

[T] he plaintiff bears the initial burden of showing that an agreement has a substantially adverse effect on competition. ... If the plaintiff meets this burden, the burden shifts to the defendant to come forward with evidence of the procompetitive virtues of the alleged wrongful conduct. . . . If the defendant is able to demonstrate procompetitive effects, the plaintiff then must prove that the challenged conduct is not reasonably necessary to achieve the legitimate objectives or that those objectives can be achieved in a substantially less restrictive manner. . . . Ultimately, if these steps are met, the harms and benefits must be weighed against each other in order to judge whether the challenged behavior is, on balance, reasonable. ${ }^{140}$

\section{NCAA Input Market Restraints Have Significant Anticompetitive Effects Requiring Procompetitive Justification}

Because NCAA member universities compete for the services of student-athletes, NCAA student-athlete eligibility rules and other input market restraints preclude or limit intrabrand competition. Relying on Mandeville Island Farms, the O'Bannon district court rejected the NCAA's assertion that plaintiffs must prove that this restraint "harms consumers by reducing

\footnotetext{
${ }^{138}$ Herbert Hovenkamp, Antitrust Balancing, 12 N.Y.U. J.L. \& BuS. 369, 371 (2016).

139 See supra notes 94-113 and accompanying text.

${ }^{140}$ Law v. NCAA, 134 F.3d 1010, 1019 (10th Cir. 1998).
} 
output or raising prices in a downstream market" ${ }^{\prime 14}$ (i.e., reduces interbrand competition in the sports entertainment market). This ruling, which was affirmed by the Ninth Circuit, ${ }^{142}$ correctly interprets Mandeville Island Farms and is consistent with Law as well as other cases holding that professional sports labor market restraints have significant anticompetitive effects under section 1 even without harming consumers.

Like the REC rule in Law, the NCAA's amateurism eligibility rules fix prices in the input market for the production of college sports. Over time the REC rule would harm consumer welfare by reducing the quality of intercollegiate athletics by misallocating labor market resources because coaches would refuse to accept artificially low salaries and seek alternative employment outside of college sports. ${ }^{143}$ Although the NIL compensation rules precluded student-athletes from receiving any compensation for their NIL rights, their effects on consumer welfare are uncertain. It also is difficult to accurately determine or predict whether other NCAA amateurism eligibility rules also cause a similar misallocation of student-athlete playing services with adverse consumer welfare effects.

These restraints may reduce the quality of intercollegiate athletics to the detriment of consumer welfare by reducing the quantity of eligible student-athletes or by causing them to turn professional earlier than if such rules did not exist in a free market. The NBA and NFL CBAs establish legally enforceable player eligibility rules that preclude employment in the NBA until reaching the age of nineteen years old, and in the NFL until three years have elapsed since graduating from high school, respectively. ${ }^{144}$ After satisfying these requirements, studentathletes with remaining college eligibility may choose to pursue an NBA or NFL career rather than continuing to play NCAA basketball or football without any payment or economic benefits in excess of the value of a full cost-of-attendance scholarship. As the Ninth Circuit observed: "athletes might well be more likely to attend college, and stay there longer, if they knew that they were earning some amount of NIL income while they were in school."145

${ }^{141}$ O'Bannon, 7 F. Supp. 3d at 992. See White v. NCAA, 2006 WL 8066802 at *4 (C.D. Cal. 2006) ("Despite the NCAA's claims, antitrust law does not require plaintiffs to plead harm specifically to "output markets" in challenging NCAA grant-in-aid cap limiting value of athletic scholarships to tuition, room and board, and books).

142 O'Bannon, 802 F.3d at 1070-072.

${ }^{143}$ Roberts, supra note 126, at 2637 n.20 ("In short, the artificial salary restraint on the REC market would result in many RECs working at jobs where they would not generate as much consumer welfare as they would at the REC jobs they would take it the free market dictated their salaries.").

${ }^{144}$ Clarett v. NFL, 369 F.3d 124 (2d. Cir. 2004), cert. denied, 544 U.S. 961 (2005).

${ }^{145} I d$. at 1073. 
Even if the NCAA's amateurism eligibility rules do not cause a misallocation of resources that harms consumer welfare, NIL compensation rules and other rules prohibiting price competition among NCAA schools likely transfer wealth from student-athletes to universities and third parties such as coaches earning high salaries, which arguably is an anticompetitive effect. $^{146}$

\section{Judicially Accepted Procompetitive Justifications Should Enhance Consumer Welfare}

In Board of Regents, the Supreme Court ruled that the NCAA has a "heavy burden" of establishing a procompetitive objective that justifies a restraint's anticompetitive effects. ${ }^{147}$ O'Bannon required the NCAA to prove the restraint "brings about some procompetitive effect in order to justify it" under the rule of reason. ${ }^{148}$ Because "the Sherman Act [is] a "consumer welfare prescription," "149 Board of Regents recognized product availability/differentiation, competitive balance, and increased output as procompetitive justifications for NCAA rules and regulations that eliminate or reduce intrabrand economic competition among NCAA schools. In other words, the NCAA must prove that a student-athlete eligibility rule or input market restraint causing significant anticompetitive effects in an intrabrand market has offsetting procompetitive effects in the interbrand entertainment market. In general, this effectively requires the NCAA to establish that the restraint benefits consumers of intercollegiate athletics.

\section{a. Product Availability/Differentiation}

Intercollegiate and professional sports have several distinguishing features and are different brands of entertainment for a variety of reasons. In general, the Supreme Court explicitly recognized that "[t]he identification of [intercollegiate athletics] with an academic tradition differentiates [it] from ... professional sports to which it might otherwise be comparable" 150 and that "the preservation of the student-athlete in higher education adds richness and diversity to intercollegiate athletics." ${ }^{.151}$ More specifically, NFL football differs from NCAA Division I FBS football (just as NBA basketball differs from Division I men's basketball) because of their differing quality of athletes, caliber of on-field competition, length of season, and methods of determining teams that participate in postseason championship competition.

${ }^{146}$ Roberts, supra note 126, at 2649-651.

${ }^{147}$ NCAA v. Bd. of Regents, 468 U.S. 85, 113 (1984).

148 O’Bannon v. NCAA, 802 F.3d 1049, 1073 (9th Cir. 2015). See United States v. Brown Univ., 5 F.3d 658, 679 (3d Cir. 1993) (requiring defendant "to demonstrate[] that its conduct promotes a legitimate goal").

${ }^{149}$ Bd. of Regents, 468 U.S. at 107.

${ }^{150}$ Id. at 101.

${ }^{151}$ Id. at 120. 
In Board of Regents dicta, the Court conflated amateurism with its clearly recognized and economically sound procompetitive defenses of brand differentiation and competitive balance by stating '[i]n order to preserve the character and quality of the 'product' [college sports], athletes must not be paid, must be required to attend class, and the like." 152 It also stated that "maintaining competitive balance among amateur athletic teams is legitimate and important"153 and noted the "revered tradition of amateurism in college sports." that "fostering competition among amateur athletic teams" is a procompetitive means of "enhance[ing] public interest in intercollegiate athletics."

For purposes of determining the underlying basis of a sports entertainment product's availability or brand differentiation, "[t]he relevant antitrust question is whether [an intrabrand restraint is necessary to] create a qualitatively distinct type of athlete and athletic product that, because of its distinctiveness, provides a large number of consumers with a product they greatly desire and could not otherwise get." ${ }^{156}$ It is not generally accepted or readily apparent that the NCAA-defined "amateur" status of student-athletes is the determinative or primary factor-or even a significant one - that distinguishes college and professional sports for purposes of their consumer appeal. ${ }^{157}$ Rather than making any unwarranted assumptions, "the question of how much of the consumer utility generated by intercollegiate athletics is dependent upon the limitations on athlete compensation is one of fact that would have to be developed in a full record," for example, by surveys and statistical evidence. ${ }^{158}$

In a pretrial ruling, the $O^{\prime}$ Bannon district court held that whether amateurism increases the popularity of Division I sports is a fact question to be resolved at trial because the parties' evidence is conflicting. ${ }^{159}$ The NCAA's experts contended that historically "consumers generally

${ }^{152} I d$. at 101.

${ }^{153} I d$. at 117.

${ }^{154} I d$. at 120.

${ }^{155} I d$. at 117.

${ }^{156}$ Roberts, supra note 126, at 2658-659.

${ }^{157} I d$. at 2659 ("Despite the Board of Regents dictum suggesting the Court already know the answer, it is not at all clear the college sports' great popularity is substantially greater because the athletes are paid only with in-kind 'academic services.'"); Mitten, University Price Competition, supra note 3, at 78-79 ("For example, alumni pride and loyalty, tradition, longstanding rivalries, national rankings, conference and national championship tournament competition, and exciting play probably contribute to the public obsession with college sports more than the 'amateur' status of college athletes.").

${ }^{158}$ Roberts, supra note 126, at 2659.

${ }^{159}$ In re NCAA Student-Athlete Name \& Likeness Licensing Litigation, 37 F. Supp. 3d 1126 (N.D. Cal. 2014). 
favor the amateur nature of college sports," and $68.9 \%$ of consumers in a recent survey were opposed to paying college football and basketball players. ${ }^{160}$ Plaintiffs' evidence "that the NCAA has changed its definition of amateurism several times over the years without significantly affecting consumer demand for its product"161 suggests that the popularity of college sports is unrelated to the NCAA's amateurism rules.

At trial, the court found that "consumer demand for FBS football and Division I basketball-related products is not driven by the restrictions on student-athlete compensation but instead by other factors such as school loyalty and geography." "162 However, it concluded:

the NCAA's restrictions on student-athlete compensation play a limited role in driving consumer demand for FBS football and Division I basketball-related products. Although they might justify a restriction on large payments to studentathletes while in school, they do not justify the rigid prohibition on compensating student-athletes, in the present or future, with any share of licensing revenue generated from the use of their names, images, and likenesses. ${ }^{163}$

The O'Bannon Ninth Circuit panel broadly construed this factual finding by determining that "the amateur nature of collegiate sports increases their appeal to consumers."164 It suggested that NCAA-defined amateurism is itself a procompetitive justification, which is contrary to trial evidence that "consumer demand typically does not decrease when athletes are permitted to receive payment, and that this general principle holds true across a wide variety of sports and competitive formats." 165 More specifically, four experts testified "that providing student-athletes with small amounts of compensation above their cost of attendance would not have a significant impact on consumer interest in college sports." 166 The dissent appropriately concluded that "the concept of amateurism is relevant only insofar as it relates to consumer interest." 167 Thus, a more accurate, evidence based conclusion is that maintaining "amateurism" is not a separate and distinct procompetitive justification for anticompetitive NCAA student-athlete eligibility rules and other input market restraints. Rather, the NCAA's amateurism rules are merely one factor differentiating intercollegiate and professional sports for purposes of product differentiation,

${ }^{160} I d$. at 1147 .

${ }^{161}$ Id. at $1147-148$.

162 O’Bannon v. NCAA, 7 F. Supp. 3d 955, 1001 (N.D. Cal. 2014).

${ }^{163} I d$.

${ }^{164}$ O’Bannon v. NCAA, 802 F.3d 1049, 1073 (9th Cir. 2015).

${ }^{165} I d$. at 1081.

${ }^{166} I d$. at 1080.

${ }^{167} I d$. at 1081 . 
which has important implications likely to be outcome determinative in analyzing whether a particular restraint actually furthers this procompetitive objective.

\section{b. Competitive Balance}

Because doing so ostensibly increases product quality and consumer welfare, Board of Regents and American Needle held that promoting on-field competitive balance among sports teams is a procompetitive justification for intrabrand restraints on the market for intercollegiate or professional player services. "Competitive balance" has the dual meaning of "parity" (i.e., the extent to which all teams playing at the same level are able to play close and exciting games during a season of competition) and "potential to change" (i.e., teams' ability to improve their relative performance in terms of on- field success vis-à-vis other teams over time). ${ }^{169}$ As applied to NCAA regulation of intercollegiate athletics, the determinative issue "is whether restricting the ways individual schools can 'compete' to improve

their relative athletic strength enhances either parity or the ability for relative change in rankings"170 among schools whose athletic teams regularly compete against each other.

The $O$ 'Bannon district court held that “a sports league's efforts to achieve the optimal competitive balance among its teams may serve a procompetitive purpose if promoting such competitive balance increases demand for the league's product." ${ }^{171}$ Although promoting competitive balance among Division I FBS football and basketball teams is a legitimate procompetitive justification, it rejected this defense because "the NCAA did not present sufficient evidence . . . that its restrictions on student-athlete compensation actually have any effect on competitive balance, let alone produce an optimal level of competitive balance."172

The court's standard is consistent with the consumer welfare objectives of antitrust law as well as judicial precedent rejecting the claims of professional sports leagues that player labor market restraints are necessary to promote competitive balance. ${ }^{173}$ However, it imposes a high burden of proof on the NCAA, which may be more than Supreme Court precedent requires. Even if the NCAA only needs to prove that a challenged restraint is reasonably necessary to promote competitive balance, it will be very difficult to justify any student-athlete eligibility

168 See supra notes 55-56 and accompanying text. However, some scholars question whether such restraints even if proven to promote competitive balance increase product quality and consumer welfare to a greater degree than "an unfettered market." Roberts, supra note 126, at 2666-669.

${ }^{169}$ Roberts, supra note 126, at 2664-665.

${ }^{170} I d$. at 2666.

${ }^{171}$ O’Bannon v. NCAA, 7 F. Supp. 3d 955, 1001 (N.D. Cal. 2014).

${ }^{172} I d$.

${ }^{173}$ See supra notes 38-60 and accompanying text. 
rules or input market restraints applicable to all of its more than 1,100 member schools. NCAA schools generally compete regularly only against others within their respective NCAA divisions (e.g., Division I FBS and FCS, II, and III) and athletic conferences, so the vast majority of association wide student-athlete amateurism eligibility rules (e.g., an absolute prohibition against student-athletes' individualized commercial exploitation of their NIL rights) or input market restraints likely are overbroad and may not survive less restrictive alternative analysis. ${ }^{174}$

\section{c. Increasing Output of Intercollegiate Athletics}

Consistent with Board of Regents, ${ }^{175}$ the $O^{\prime}$ Bannon district court held that increasing 'the total 'output' of Division I football and basketball, as measured by the total number of teams, players, scholarships, and games ... is potentially procompetitive because it increases output in the relevant market." 176 At trial, it found that the NCAA's NIL compensation rules do not increase output in this market because the NCAA did not prove that "a significant number of schools choose to compete in Division I because of a "philosophical commitment to amateurism."177 Moreover, "to the extent that schools achieve any cost savings by not paying their studentathletes, there is no evidence that those cost savings are being used to fund

${ }^{174}$ To illustrate this point, it should be noted that Division II amateurism rules to allow prospective student-athletes, after initial full-time enrollment, to (1) receive "educational expenses" from the USOC or a professional team/league; (2) receive "actual and necessary expenses from an outside amateur sports team or organization;" (3) earn "awards based on performance in outside competition;" (4) borrow from potential future earning to purchase "insurance against disabling injury or illness;" (5) "participat[e] in institutional, charitable, or educational promotions or fundraising activities;" and (6) receive and keep "elite-level participation" funds connected to the USOC's Operation Gold Program. 2016-17 NCAA DIVISION II MANUAL art. 12.1.3 (2016). Similarly, Division III amateurism rules allow prospective student-athletes to accept prize money based on finish, sign a contract with a professional team, enter a draft and be drafted, and compete on a team with professionals. Student-athletes cannot remain under contract while competing at a Division III institution, and a student-athlete who signs a contract prior to enrollment must end the relationship with the professional team and sever all terms of the contract before enrolling at the Division III level. Unlike Division II, Division III student-athletes cannot have received "pay to play." 2016-17 NCAA DIVISION III MANUAL art. 12.1 .3 (2016). In April 2002, the Division I Management Council considered, but rejected, similar amateurism rules, including proposals to permit student-athletes to enter professional drafts and compete as professionals while retaining limited eligibility to compete at Division I intercollegiate athletics in the future.

${ }^{175}$ NCAA v. Bd. of Regents, 468 U.S. 85, 114 (1984).

${ }^{176}$ O’Bannon v. NCAA, 7 F. Supp. 3d 955, 1152 (N.D. Cal. 2014).

${ }^{177}$ Id. at 1004 . 
additional teams or scholarships." $" 178$

The court rejected the NCAA's defense that its amateurism rules enable its member schools to offer and fund women's sports and less popular men's sports because it "is not a legitimate procompetitive justification." "179 It explained: "The NCAA cannot restrain competition in the 'college education' market for Division I football and basketball recruits or in the 'group licensing' market for Division I football and basketball teams' publicity rights in order to promote competition in those markets for women's sports or less prominent men's sports." 180

Its rejection of cross subsidization as a procompetitive defense to NCAA amateurism rules that fix prices for student-athletes' playing services is consistent with Brown University, which held that the Ivy Overlap Group's agreement to eliminate price competition for talented students "cannot be justified solely on the basis of social welfare concerns" such as increasing the socioeconomic diversity of their student bodies. ${ }^{181}$

\section{d. Integration of Education and Athletics}

In O'Bannon, both the district court and Ninth Circuit held that integrating academics and

\section{${ }^{178} I d$.}

${ }^{179} I d$. at 1151.

${ }^{180} I d$. It ruled this defense also fails because financial support for these sports could be provided through less restrictive alternatives such as mandating "Division I schools and conferences redirect a greater portion of the licensing revenue generated by football and basketball to these other sports." Id. Moreover, Title IX, a federal law requiring gender equity in intercollegiate athletics, and NCAA rules mandating that Division I FBS universities offer a minimum number of intercollegiate sports combine to require the provision of women's and men's nonrevenue intercollegiate sports participation opportunities. However, "[g]iven the economic incentives of the profit-maximizing athletic director, one would expect 'surplus' nonrevenue sports to be cut or their budgets reduced in favor of the income-generating sports" of football and men's basketball. Daniel R. Marburger \& Nancy Hogshead-Makar, Is Title IX Really to Blame for the Decline in Intercollegiate Men's Nonrevenue Sports?, 14 MARQ. SPORTS L. REV. 65, 92 (2003). Acknowledging that nonrevenue Division I sports provide an opportunity for elite studentathletes to derive the physical, mental, and social benefits of intercollegiate athletics competition, one scholar asserts that considering their substantial economic costs and that similar social benefits could be achieved by operating them as club or Division III sports, "it becomes difficult to conclude that continued subsidization of these sports [by revenue generating sports] is warranted as a matter of public policy." Stephen F. Ross, Radical Reform of Intercollegiate Athletics: Antitrust and Public Policy Implications, 86 TUL. L. REV. 933, 944 (2012).

${ }^{181}$ United States v. Brown Univ., 5 F.3d 658, 669 (3d Cir. 1993). 
athletics is a procompetitive justification because it enhances the quality of higher education services provided to student-athletes. ${ }^{182}$ Both courts rejected the NCAA's defense that denying student-athletes any compensation other than athletic scholarships, including specifically pursuant to its NIL compensation rules, achieves this objective. ${ }^{183}$ Absent this restraint, the district court found that "schools' incentives to support their student-athletes academically would remain changed," so they would satisfy NCAA academic progress rules and remain eligible to participate in intercollegiate athletics. ${ }^{184}$ It also found that absent this restraint, student-athletes' incentive to perform well academically would not decline and might even increase if "if they were required to meet these academic requirements as a condition of receiving [NIL compensation]." "185 The court concluded "the NCAA may not use this goal to justify its sweeping prohibition on any student-athlete compensation, paid now or in the future, from licensing revenue generated from the use of student-athletes' names, images, and likenesses," ${ }^{186}$ with which the Ninth Circuit majority disagreed in applying less restrictive alternative analysis. ${ }^{187}$

\section{Less Restrictive Alternative Analysis: A Useful Tool To Invalidate Restraints Not Reasonably Necessary To Produce Intercollegiate Athletics}

Although its use has not been explicitly endorsed by the Supreme Court, lower courts generally use less restrictive alternative analysis in applying the rule of reason. ${ }^{188}$ Most circuit courts require the plaintiff to prove the existence of a less restrictive alternative, which varies in a range from what is "least restrictive' to 'reasonably necessary" to achieve the defendant's procompetitive objectives. ${ }^{189}$ It considers possible alternative action other than the challenged restraint to achieve a procompetitive objective and avoids the need for judicial determination and comparison of net competitive effects in a market with and without the challenged restraint. ${ }^{190}$

182 O'Bannon, 7 F. Supp. 3d at 1002-003; O'Bannon v. NCAA 802 F.3d 1049, 1073 (9th Cir. 2015).

${ }^{183}$ O'Bannon, 7 F. Supp. 3d at 1003; O'Bannon, 802 F.3d at 1073.

${ }^{184}$ O'Bannon, 7 F. Supp. 3d at 1003.

${ }^{185} I d$.

${ }^{186} I d$.

${ }^{187}$ O'Bannon, 802 F.3d at 1076-079.

${ }^{188}$ Gabriel A. Feldman, The Misuse of the Less Restrictive Alternative Inquiry in Rule of Reason Analysis, AM. U. L. REV. 562, 562-63 (2009).

${ }^{189} I d$. at 583 .

${ }^{190}$ C. Scott Hemphill, Less Restrictive Alternatives in Antitrust Law, 116 COL. L. REV. 927, 937 (2016). 
Properly applied, less restrictive alternative analysis is a useful judicial analytical tool to determine if a sports industry restraint is reasonably necessary in cases in which there are anticompetitive effects in one market (e.g., reduction of intrabrand competition in the player services input market) and procompetitive effects in another market (e.g., promotion of interbrand competition in the entertainment market). In unique industries such as professional or intercollegiate sports that require agreements among competing clubs or universities to produce on-field competition in a form attractive to consumers, there is the danger that it "can be used in almost any case to strike down otherwise procompetitive rules" ${ }^{\prime 191}$ or to judicially micromanage their production. To ameliorate this risk, the plaintiff should have the burden of proving a "dominant alternative" that is "not only less restrictive, but also equally (or more) effective" in achieving defendant's procompetitive objective. ${ }^{192}$

In O'Bannon, the Ninth Circuit required plaintiffs to prove that the NCAA's procompetitive objectives of promoting amateurism and integrating academics with athletics "can be achieved in a substantially less restrictive manner." 193 This is the same standard adopted by Law and Smith in applying less restrictive alternative analysis to other NCAA and professional sports league input market restraints that reduce intrabrand competition for the services of coaches and professional athletes. ${ }^{194}$ The court acknowledged Board of Regents' admonition to "generally afford the NCAA 'ample latitude' to superintend college sports"195 as well as that "courts should not use antitrust law to make marginal adjustments to broadly reasonable market restraints" or tweak every market restraint that the court believes could be improved. "196 It required plaintiffs to "make a strong evidentiary showing its alternatives are viable" (i.e., "virtually as effective' in serving the procompetitive purposes of the NCAA's current rules and 'without significantly increased cost"'). ${ }^{197}$

Applying this standard, which effectively required the plaintiffs to prove a "dominant alternative," the Ninth Circuit ruled that allowing NCAA universities to provide full cost-ofattendance scholarships "would have virtually no impact on amateurism . . . because all the

${ }^{191}$ Roberts, supra note 126 , at 2670.

192 Hemphill, supra note 190, at 943.

193 O’Bannon v. NCAA, 802 F.3d 1049, 1070 (9th Cir. 2015).

${ }^{194}$ Law v. NCAA, 134 F.3d 1010, 1019 (10th Cir. 1998) ("plaintiff then must prove that the challenged conduct is not reasonably necessary to achieve the legitimate objectives or that those objectives can be achieved in a substantially less restrictive manner"); Smith v. Pro Football, Inc., 593 F.2d 1173, 1187 (D.C. Cir. 1978) (requiring plaintiff to prove "significantly less anticompetitive alternatives").

195 O'Bannon, 802 F.3d at 1074.

${ }^{196} I d$. at 1075.

${ }^{197}$ Id. at 1074. 
money given to students would be going to cover their 'legitimate costs' to attend school." 198 It also would not impede their integration of student-athletes into their academic communities. Because new NCAA rules that became effective after the district court's decision currently permit schools to offer full cost-of-attendance scholarships, it found that this alternative would not significantly increase their costs.

Based on its ruling that maintaining amateurism is a legitimate procompetitive justification, the O'Bannon majority used less restrictive alternative analysis to rule that the NCAA's former rules capping the value of an athletic scholarship below the full cost-ofattendance is broader than reasonably necessary to achieve this objective. This holding enables the NCAA to maintain the unique core characteristic of intercollegiate athletics (i.e., its academic tradition), which is a significant distinguishing factor vis-à-vis professional sports, and does not inhibit the integration of student-athletes into universities. Although this holding effectively redefines NCAA "amateurism" and arguably does constitute the application of a de facto least restrictive alternative standard in this particular case, invalidating the NIL zero compensation rules is judicially appropriate because this restraint "is patently and inexplicably stricter than necessary." 199 In principle, this stringent standard appropriately precludes the use of less restrictive alternative analysis to invalidate NCAA student-athlete eligibility rules and input market restraints that are reasonably necessary to further procompetitive objectives. If adopted and followed by other courts, it should avoid judicial micromanaging of intercollegiate athletics.

The O'Bannon majority reversed the district court's determination that allowing Division I basketball and FBS football players to receive \$5,000 cash stipends for their NIL rights after their intercollegiate athletics career ends is a substantially less restrictive alternative. By definition, allowing them to receive compensation "untethered to their education expenses" is not a "virtually as effective" means of maintaining amateurism in NCAA athletics. In other words, despite the substantially commercialized nature of Division I basketball and FBS football, the majority holds that all NIL rights compensation received by those who currently or formerly played these two sports must be tethered to the costs of their educational opportunities. ${ }^{200}$

${ }^{198} I d$.

${ }^{199} \mathrm{Id}$.

${ }^{200}$ Some commentators have suggested that permitting former players to receive NIL compensation if they maintained their academic eligibility while playing intercollegiate sports and use this money only for educational purposes would be an even less restrictive alternative consistent with this standard. Roger M. Groves, A Solution for the Pay for Play Dilemma of College Athletes: A Novel Compensation Structure Tethered to Amateurism and Education, 17 Tex. Rev. Ent. \& Sports L. 101, 123-124 (2016). Other possibilities are an NCAA postgraduate scholarship program or the payment of academic achievement awards to former intercollegiate athletes who meet certain academic requirements or goals. All reforms would have to comply with Title IX gender equity requirements that require proportionately equal benefits and 
If maintaining amateurism is relevant only to the extent necessary to distinguish intercollegiate and professional sports from the perspective of consumers, the dissent's view that the district court properly used less restrictive analysis to fashion a remedy to achieve this objective is incorrect. Based on the record evidence, principled rule of reason analysis consistent with the objectives of antitrust law would have required the district court to rule that NCAA rules fixing student-athletes' NIL compensation at zero are not reasonably necessary to maintain the limited role of amateurism in product differentiation and, therefore, are illegal and unenforceable. Its use of less restrictive alternative analysis to judicially determine a reasonable amount of NIL rights compensation for student-athletes is erroneous because "[ $t]$ he point of the less restrictive alternative test is not to turn the antitrust court into a price regulator, but rather to find competitive alternatives to a challenged restraint." ${ }^{201}$ However, the appropriate antitrust remedy of simply invalidating the NCAA's zero NIL compensation rules, which would enable free market competition to determine student-athletes' payments from their respective universities and third parties for use of their NILs, would be the first step towards professionalization of intercollegiate sports with corresponding adverse consequences. ${ }^{202}$

Although it needs to be applied with judicial caution and consistent with the stringent $O$ 'Bannon standard, the use of less restrictive alternative analysis may be particularly useful in determining whether challenged NCAA student-athlete eligibility rules (e.g., transfer rules) or other input market restraints (e.g., per sport limits on the number of athletic scholarships) are reasonably necessary to achieve competitive balance in intercollegiate athletics. An NCAA or Division-wide restraint may be overbroad; a substantially less restrictive alternative that achieves legitimate procompetitive objectives relevant to intercollegiate sports may be permitting athletic conferences within NCAA Divisions to independently establish their own rules, just as NCAA autonomy legislation is enabling the Division I Power Five conferences to do. ${ }^{203}$ For example, a conference rule imposing an academic residency requirement for intra-conference student-athlete transfers is much less restrictive than a similar NCAA or Division rule that applies nationwide. ${ }^{204}$

treatment for both female and male intercollegiate athletes. Mitten, Musselman \& Burton, supra note 4 at $841-842$.

${ }^{201}$ Hovenkamp, supra note 138 , at 378.

${ }^{202}$ Mitten \& Ross, supra note 4 at 853-855 (advocating that professionalization of commercialized college sports is not the solution and identifying potential resulting problems if this occurs).

${ }^{203}$ Michelle Brutlag Hosick, Board Adopts New Division I Structure, NCAA.ORG (Aug. 7, 2014), http://www.ncaa.org/about/resources/media-center/news/board-adopts-new-division-istructure.

${ }^{204}$ Tanaka v Pac. Ten Conference, 252 F.3d 1059 (9th Cir. 1996) (dismissing antitrust challenge to Pac-10 intra-conference transfer rule because it does not have significant anticompetitive effects). 
Some have suggested that "the shifting of amateurism rules from the national level to the conference level, with individual conferences competing against one another to set the most desirable terms of athlete employment" 205 as a possible less restrictive alternative. However, this would require judicial rejection of an amateur model of intercollegiate athletics with all payments to student-athletes tethered to the costs of educational opportunities. On the other hand, courts should not improperly micromanage NCAA governance of intercollegiate athletics by tweaking restrictions proven as a matter of fact to further competitive balance among university athletic teams that regularly play games and compete in championship competitions against each other; for example, by enjoining enforcement of the current rule capping Division I FBS football scholarship at eighty-five in favor of a cap of ninety scholarships.

\section{Balancing Anticompetitive and Procompetitive Effects}

O'Bannon and Law disagree regarding whether a fourth step, the balancing of anticompetitive effects, is a necessary requirement of full rule of reason analysis if the parties satisfy their respective burdens of proof. Although this is an important issue of general antitrust jurisprudence and Law represents the majority judicial view, ${ }^{206}$ the antitrust validity of most NCAA student-athlete eligibility rules or other input market restraints can be judicially determined without any balancing to determine the net competitive effects of the restraint, which is a very complex and difficult endeavor. ${ }^{207}$ One scholar has observed: "In the vast majority of rule of reason cases, even complex ones like O'Bannon, real balancing is not necessary. The series of steps - first prima facie case, then defense, and occasionally inquiry into less restrictive alternatives-will be sufficient." ${ }^{208}$ Although one scholar suggests that the O'Bannon majority erred by not balancing the anticompetitive and procompetitive effects of the NIL zero compensation rules after determining that permitting a $\$ 5,000$ stipend is not a less restrictive

${ }^{205}$ Marc Edelman, How Antitrust Law Could Reform College Football: Section 1 of the Sherman Act and the Hope for Tangible Change, 68 Rutgers U. L. Rev. 809, 823 (2016).

${ }^{206}$ Michael A. Carrier, How Not to Apply the Rule of Reason: The O'Bannon Case, 114 Mich. L. Rev. First Impressions 73, 77 (2015) ("My review of more than 700 cases spanning a 30-year period--from 1977 (the date of the first Rule-of-Reason case in the modern era, Continental T.V., Inc. v. GTE Sylvania Inc.) to May 2009--led to the unmistakable conclusion that courts applying the Rule of Reason engage in a four-stage framework, examining (1) anticompetitive effect, (2) procompetitive justification, (3) less restrictive alternative or reasonable necessity, and (4) balancing.")

${ }^{207}$ Hovenkamp, supra note 138, at 370. ("'Balancing' requires values that can be cardinally measured and weighed against each other. The factors that are supposedly balanced in Sherman Act cases almost never fit this description. Even if the things requiring balancing did come in cardinal units, most times the courts would not have the tools necessary to make and apply the measurements.").

${ }^{208}$ Id. at 383 . 
alternative ${ }^{209}$ doing so would not have changed their remedy of permitting plaintiffs to receive a stipend not to exceed the value of a full cost-of-attendance athletic scholarship at their respective universities.

\section{Conclusion}

Case-by-case litigation to resolve the antitrust validity of particular NCAA studentathlete eligibility rules is not an optimal method of externally regulating intercollegiate sports competition among nonprofit institutions of higher education. It has resulted in conflicting judicial decisions creating legal uncertainty rather than a principled and predictable application of antitrust law as well as being very expensive ${ }^{210}$ and time consuming. ${ }^{211}$ In applying antitrust law, with the exception of $O$ 'Bannon, courts traditionally have been very deferential to the NCAA and upheld its self-defined amateurism regulations without close scrutiny under the rule of reason. This approach is consistent with judicial, NLRB, and state legislative refusals to professionalize intercollegiate athletics by characterizing student-athletes as "employees" under labor, employment, and worker's compensation laws, but it is inconsistent with general and professional sports antitrust law principles. To enable the achievement of legitimate social welfare objectives in higher education (which are not procompetitive objectives for purposes of antitrust law), an alternative system of regulating intercollegiate athletics that provides antitrust immunity is a better legal regime. The use of antitrust law is a second best solution, but judicial adoption of the foregoing recommendations will better promote consumer welfare, protect student-athletes' economic rights, and permit the NCAA to promote the unique features of intercollegiate sports without unwarranted judicial micromanagement.

${ }^{209}$ Carrier, supra note 206, at 77-78.

${ }^{210}$ A federal judge awarded $\$ 42.3$ million in attorneys' fees to the O'Bannon plaintiffs, which the NCAA must pay. Steve Berkowitz, Federal Judge: NCAA Must Pay \$42.3 Million in O'Bannon Anti-Trust Case, USA TODAY (Mar. 31, 2016), http://www.usatoday.com/story/sports/college/2016/03/31/federal-judge-ncaa-must-pay-423million-obannon-anti-trust-case/82493298/. In Law, the plaintiffs were awarded approximately \$20 million in attorneys' fees and costs. Mitten, supra note 18 at 245.

${ }^{211}$ For example, more than seven years elapsed from when the O'Bannon Class Action Complaint (available at 2009 WL 2416720) was filed on July 21, 2009 until the Supreme Court denied certiorari on October 3, 2016. ; O’Bannon v. NCAA, 137 S. Ct. 277 (2016). 